\title{
Mapping of Natural Radioactivity in Soil Samples of Kufa Districts, Iraq Using GIS Technique
}

Lubna A. Alasadi

University of Kufa Faculty of Sciences

Ali Abid Abojassim ( $\nabla$ ali.alhameedawi@uokufa.edu.iq)

University of Kufa https://orcid.org/0000-0001-5950-5220

\section{Research Article}

Keywords: Natural radioactivity, gamma ray, soil, GIS, and Kufa districts.

Posted Date: September 14th, 2021

DOI: https://doi.org/10.21203/rs.3.rs-862397/v1

License: (c) (1) This work is licensed under a Creative Commons Attribution 4.0 International License. Read Full License 


\title{
Mapping of Natural Radioactivity in Soil Samples of Kufa Districts, Iraq Using GIS
}

Technique

Lubna A. Alasadi and Ali Abid Abojassim*

University of Kufa, Faculty of Science, Department of Physics, Al-Najaf, Iraq

*Corresponding author Email: ali.alhameedawi@uokufa.edu.iq

\begin{abstract}
\end{abstract}
The aim from this work is to detect and draw the natural radioactivity of (uranium-238, thorium-232 and potassium-40) levels in soil samples that taken from Kufa districts, Najaf governorate, Iraq. The detection system used in study is $\mathrm{NaI}(\mathrm{Tl})$ with "3x3" dimension, while maps were drawn by geographic information system (GIS). Some radiological parameters were calculated depending on measuring of specific activity for ${ }^{238} \mathrm{U},{ }^{232} \mathrm{Th}$, and ${ }^{40} \mathrm{~K}$. The results of the average value with standard error in all samples of the present study for ${ }^{238} \mathrm{U},{ }^{232} \mathrm{Th},{ }^{40} \mathrm{~K}$, and ${ }^{235} \mathrm{U}$ were $6.2 \pm 0.74,6.41 \pm 0.82,278.10 \pm 19.43$, and $0.28 \pm 0.03 \mathrm{~Bq} / \mathrm{kg}$, respectively. The specific activity of Uranium-238, Thourium-232, poasium-40 and Uranium-235 found in all soil samples were within the safety limit reported by UNSCEAR, except three samples have poasium-40 higher than safety limit. Also, the results of radiological parameters were all found to be below OECD, UNSCEAR safety limit. Generally, the average of specific activity in soil collected arranged of potassium-40 > thorium-232 > uranium-238. Mapping GIS for natural radioactivity and some radiological parameters were successfully draw for the study area. Finally, natural radioactivity and radiological parameters for soil samples at Kufa districts were safety.

Keyword: Natural radioactivity, gamma ray, soil, GIS, and Kufa districts.

\section{Introduction}

Today the most important and serious problems that face humanity and other living kinds is environmental pollution. Radioactive materials and radiation pose a major threat to the lives of humans and organisms in general [1]. Radionuclides found in nature are usually categorized into 
two distinct forms cosmogenic and terrestrial origin arising from the earth crusts and earth born materials [2]. Among the natural radionuclides, uranium, thorium and their progenies are ubiquitous; mostly contribute to the human radiation exposure. In this study, the focus on gammaray that emitting daughter nuclei in the decay series of ${ }^{238} \mathrm{U},{ }^{232} \mathrm{Th}$, and ${ }^{40} \mathrm{~K}$ [3]. The decay series of ${ }^{238} \mathrm{U}$ and ${ }^{232} \mathrm{Th}$ are characterized more or less by the initial part ruled by alpha decay and a part ruled by gamma-ray emission. This contributes to the difficulty in the radioactive measurements. During a series of radioactive decays, the original radioactive (parent) nucleus decays to another radioactive (daughter) nucleus until the end of the series, where a stable nucleus is formed ${ }^{206} \mathrm{~Pb}$ in the case of ${ }^{238} \mathrm{U}$ series and ${ }^{208} \mathrm{~Pb}$ for ${ }^{232} \mathrm{Th}$ )[4]. Isotopes which include radionuclides such as ${ }^{238} \mathrm{U},{ }^{232} \mathrm{Th}$, and ${ }^{235} \mathrm{U}$ as well as ${ }^{40} \mathrm{~K}$ are found in all mutual types of rock and soil. Furthermore, these radionuclides disintegrate into other nuclides that are also radioactive, thus forming a decay chain. Natural and anthropogenic radionuclides in the environment may enter the human body through inhalation and ingestion, therefore; vital to study these radionuclides in each environmental compartment (atmosphere, hydrosphere, lithosphere and biosphere) worldwide and to evaluate the risk hazards on human health among the many investigations concerning naturally occurring isotopes [5].Because people are exposed to natural radiation with varying amounts depending on natural radioactive minerals prevalent in each location throughout the world, natural environmental radioactivity and radiation in soil have piqued researchers' attention. The principal source of radiation contamination is direct drops from the atmosphere on plants. Finished products of fission are strong maintained and absorbed and by particles of soil, similar to nature radio-actives, which were widely dispersed at various depths of soil. As a result, understanding the distribution of radionuclides in soils is critical for reducing health hazards to the impacted population. A number of studies have determined natural radioactivity in soil and maps using GIS [7-10]. In order to obtain baseline data from nature radiation levels, determine nature radiation at environmental isotopes haven carry out in several nations. As a result, the goal of this study is drawing a map using GIS for the specific 
51 activity of natural radionuclides ${ }^{238} \mathrm{U},{ }^{232} \mathrm{Th}$, and ${ }^{40} \mathrm{~K}$ in soil samples collected from 40 locations at

52 Kufa districts, Najaf Governorate, Iraq. Which measured by sodium iodide with thallium tainted.

\section{Area of Study}

Kufa district is located about (8.99) $\mathrm{km}$ eastern of AL-Najaf province, it positioned province of AL-Najaf is situated in the south-western region of Iraq, occupying an area of (28537) $\mathrm{km}^{2}$, the sub-districts under the district of Kufa are the sub-district of Al-Abbassiya and the subdistrict of Al-Huriya. We are studying forty locations that located in Kufa city to measure natural radioactivity and mapping it.

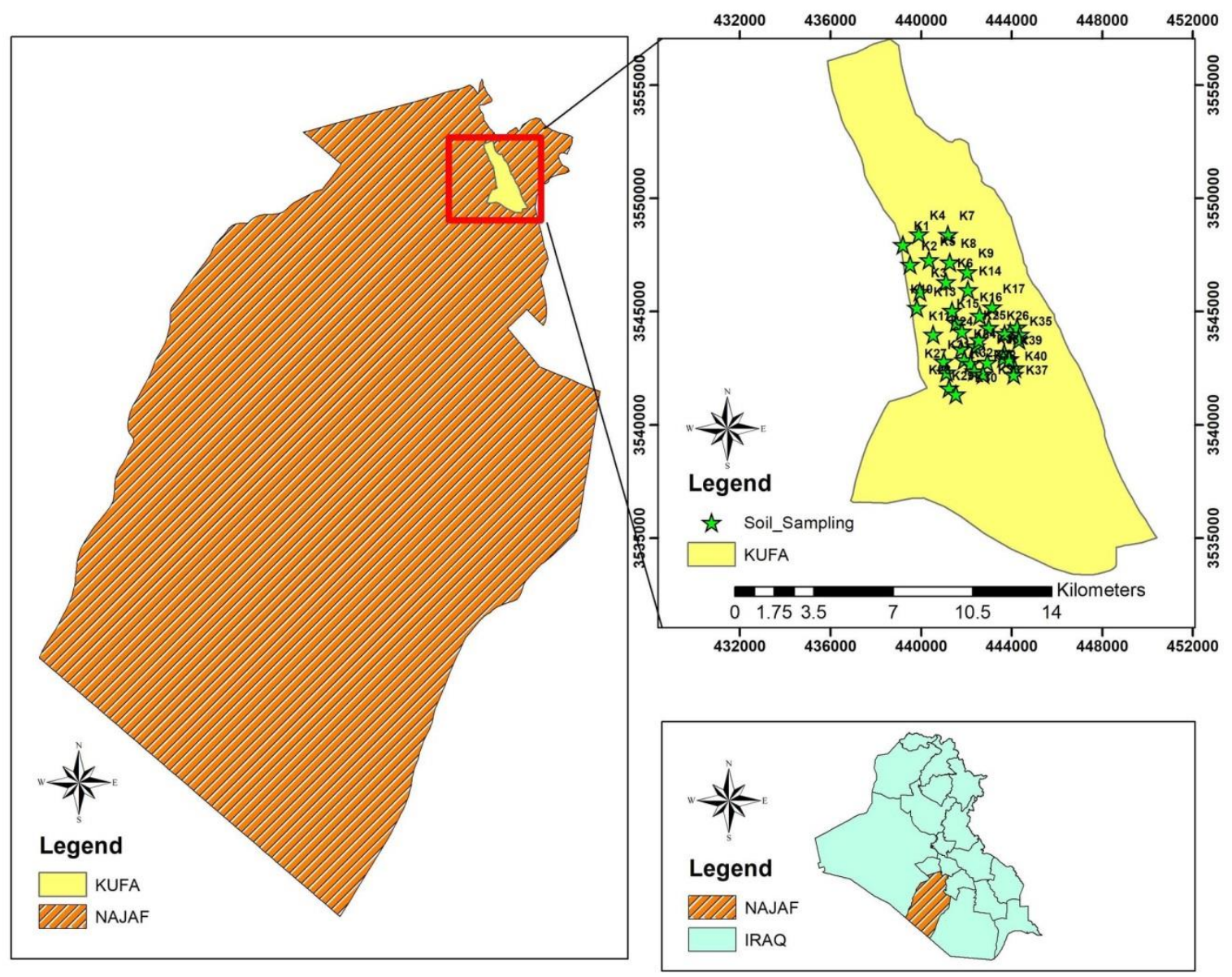




\section{Materials and methods}

3.1. Collection Samples

40 samples of soil were chosen from Kufa district region, the study area were divided administratively for the purpose of collecting samples, which collected randomly from various locations in districts of province. The samples were taken with a depth of $15 \mathrm{~cm}$, and determined the coordinates of the readings as well as drawn using Global Positioning System (GPS) and GIS (ArcGIS 10.7.1.) as shown in Table 1 and Figure1.

Table 1. Names and locations with Coordinates of Soil samples of present study

\begin{tabular}{|c|c|c|c|c|}
\hline No. & Name of Samples & Sample code & \multicolumn{2}{|c|}{ Coordinates } \\
\hline 1 & Maysan 1 & $\mathrm{K} 1$ & $44^{\circ} 21^{\prime} 21.5^{\prime \prime} \mathrm{E}$ & $32^{\circ} 03^{\prime} 59.5^{\prime \prime} \mathrm{N}$ \\
\hline 2 & Maysan 2 & $\mathrm{K} 2$ & $44^{\circ} 21^{\prime} 33.1^{\prime \prime} \mathrm{E}$ & $32^{\circ} 03^{\prime} 30.5^{\prime \prime} \mathrm{N}$ \\
\hline 3 & Maysan 3 & $\mathrm{K} 3$ & $44^{\circ} 21^{\prime} 50.4^{\prime \prime} \mathrm{E}$ & $32^{\circ} 02^{\prime} 51.7^{\prime \prime} \mathrm{N}$ \\
\hline 4 & Alwat Alfahal 1 & $\mathrm{K} 4$ & $44^{\circ} 21^{\prime} 47.7^{\prime \prime} \mathrm{E}$ & $32^{\circ} 04^{\prime} 13.8^{\prime \prime} \mathrm{N}$ \\
\hline 5 & Alwat Alfahal 2 & $\mathrm{K} 5$ & $44^{\circ} 22^{\prime} 06.1^{\prime \prime} \mathrm{E}$ & $32^{\circ} 03^{\prime} 37.2^{\prime \prime} \mathrm{N}$ \\
\hline 6 & Alwat Alfahal 3 & $\mathrm{K} 6$ & $44^{\circ} 22^{\prime} 34.3^{\prime \prime} \mathrm{E}$ & $32^{\circ} 03^{\prime} 06.6^{\prime \prime} \mathrm{N}$ \\
\hline 7 & Alzarga 1 & $\mathrm{K} 7$ & $44^{\circ} 22^{\prime} 38.1^{\prime \prime} \mathrm{E}$ & $32^{\circ} 03^{\prime} 39.6^{\prime \prime} \mathrm{N}$ \\
\hline 8 & Alzarga 2 & $\mathrm{K} 8$ & $44^{\circ} 22^{\prime} 39.7^{\prime \prime} \mathrm{E}$ & $32^{\circ} 03^{\prime} 34.6^{\prime \prime} \mathrm{N}$ \\
\hline 9 & Alzarga 3 & $\mathrm{K} 9$ & $44^{\circ} 23^{\prime} 10.0^{\prime \prime} \mathrm{E}$ & $32^{\circ} 03^{\prime} 20.0^{\prime \prime} \mathrm{N}$ \\
\hline 10 & Middle Euphrates Center & $\mathrm{K} 10$ & $44^{\circ} 21^{\prime} 46.0 " \mathrm{E}$ & $32^{\circ} 02^{\prime} 28.2^{\prime \prime} \mathrm{N}$ \\
\hline 11 & Kufa University 1 & $\mathrm{K} 11$ & $44^{\circ} 22^{\prime} 13.7^{\prime \prime} \mathrm{E}$ & $32^{\circ} 01^{\prime} 49.7^{\prime \prime} \mathrm{N}$ \\
\hline 12 & Kufa University 2 & $\mathrm{K} 12$ & $44^{\circ} 22^{\prime} 30.3^{\prime \prime} \mathrm{E}$ & $32^{\circ} 01^{\prime} 12.1^{\prime \prime} \mathrm{N}$ \\
\hline 13 & Alsahla & $\mathrm{K} 13$ & $44^{\circ} 22^{\prime} 44.8^{\prime \prime} \mathrm{E}$ & $32^{\circ} 02^{\prime} 22.6^{\prime \prime} \mathrm{N}$ \\
\hline 15 & Palm Street area & $44^{\circ} 23^{\prime} 11.4^{\prime \prime} \mathrm{E}$ & $32^{\circ} 02^{\prime} 53.1^{\prime \prime} \mathrm{N}$ \\
\hline
\end{tabular}




\begin{tabular}{|c|c|c|c|c|}
\hline 16 & Alsehilia 1 & K16 & $44^{\circ} 23^{\prime} 31.9^{\prime \prime} \mathrm{E}$ & $32^{\circ} 02^{\prime} 17.0^{\prime \prime} \mathrm{N}$ \\
\hline 17 & Alsehilia 2 & K17 & $44^{\circ} 23^{\prime} 51.1^{\prime \prime E}$ & $32^{\circ} 02^{\prime} 29.1^{\prime \prime N}$ \\
\hline 18 & Almutanabi & K18 & $44^{\circ} 23^{\prime} 02.2^{\prime \prime} \mathrm{E}$ & $32^{\circ} 01^{\prime} 54.4^{\prime \prime} \mathrm{N}$ \\
\hline 19 & Aljamea & K19 & $44^{\circ} 23^{\prime} 45.8^{\prime \prime} \mathrm{E}$ & $32^{\circ} 02^{\prime} 00.1^{\prime \prime N}$ \\
\hline 20 & Aljomhoria & K20 & $44^{\circ} 24^{\prime} 22.6^{\prime \prime E}$ & $32^{\circ} 01^{\prime} 56.2^{\prime \prime} \mathrm{N}$ \\
\hline 21 & Aljdaidaat & K21 & $44^{\circ} 24^{\prime} 33.2^{\prime \prime E}$ & $32^{\circ} 02^{\prime} 01.1^{\prime \prime N}$ \\
\hline 22 & Alshorta & K22 & $44^{\circ} 23^{\prime} 00.7 " \mathrm{E}$ & $32^{\circ} 01 ' 30.3^{\prime \prime N}$ \\
\hline 23 & Kenda 1 & K23 & $44^{\circ} 23^{\prime} 24.2^{\prime \prime} \mathrm{E}$ & $32^{\circ} 01 ' 33.5 " \mathrm{~N}$ \\
\hline 24 & Almolimeen & K24 & $44^{\circ} 23 ' 29.9^{\prime \prime} \mathrm{E}$ & $32^{\circ} 01^{\prime} 42.8^{\prime \prime N}$ \\
\hline 25 & Alwakaf & $\mathrm{K} 25$ & $44^{\circ} 24^{\prime} 13.2^{\prime \prime} \mathrm{E}$ & $32^{\circ} 01^{\prime} 50.1^{\prime \prime N}$ \\
\hline 26 & Alrashadiya & K26 & $44^{\circ} 24^{\prime} 37.8^{\prime \prime E}$ & $32^{\circ} 01^{\prime} 50.7^{\prime \prime N}$ \\
\hline 27 & Industrial District 1 & K27 & $44^{\circ} 22^{\prime} 34.9^{\prime \prime E}$ & $32^{\circ} 00^{\prime} 56.3^{\prime \prime N}$ \\
\hline 28 & Industrial District 2 & K28 & $44^{\circ} 22^{\prime} 40.1^{\prime \prime E}$ & $32^{\circ} 00^{\prime} 32.6^{\prime \prime} \mathrm{N}$ \\
\hline 29 & Almatar & K29 & $44^{\circ} 22^{\prime} 51.3^{\prime \prime} \mathrm{E}$ & $32^{\circ} 00^{\prime} 24.7^{\prime \prime N}$ \\
\hline 30 & Tamoz & K30 & $44^{\circ} 23^{\prime} 04.7 " \mathrm{E}$ & $32^{\circ} 01 ' 14.3^{\prime \prime} \mathrm{N}$ \\
\hline 31 & Kenda 2 & K31 & $44^{\circ} 23^{\prime} 15.0^{\prime \prime} \mathrm{E}$ & $32^{\circ} 01^{\prime} 07.9^{\prime \prime} \mathrm{N}$ \\
\hline 32 & Maytham Altamaar 1 & K32 & $44^{\circ} 23 ' 23.6 " \mathrm{E}$ & $32^{\circ} 00^{\prime} 57.3^{\prime \prime} \mathrm{N}$ \\
\hline 33 & Maytham Altamaar 2 & K33 & $44^{\circ} 23^{\prime} 42.9^{\prime \prime} \mathrm{E}$ & $32^{\circ} 01^{\prime} 10.4^{\prime \prime} \mathrm{N}$ \\
\hline 34 & Alsafeer & K34 & $44^{\circ} 24^{\prime} 11.8 " \mathrm{E}$ & $32^{\circ} 01 ' 23.4^{\prime \prime} \mathrm{N}$ \\
\hline 35 & Alkareeat & K35 & $44^{\circ} 24^{\prime} 39.0^{\prime \prime E}$ & $32^{\circ} 01^{\prime} 48.3^{\prime \prime} \mathrm{N}$ \\
\hline 36 & Alforat 1 & K36 & $44^{\circ} 24^{\prime} 12.1^{\prime \prime} \mathrm{E}$ & $32^{\circ} 01^{\prime} 16.5^{\prime \prime} \mathrm{N}$ \\
\hline 37 & Alforat 2 & K37 & $44^{\circ} 24^{\prime} 30.6^{\prime \prime E}$ & $32^{\circ} 01^{\prime} 02.6^{\prime \prime N}$ \\
\hline 38 & Role of cement plant & K38 & $44^{\circ} 23^{\prime} 36.6^{\prime \prime} \mathrm{E}$ & $32^{\circ} 00^{\prime} 52.9^{\prime \prime} \mathrm{N}$ \\
\hline 39 & Alsadar-Third 1 & K39 & $44^{\circ} 24^{\prime} 21.2^{\prime \prime} \mathrm{E}$ & $32^{\circ} 01 ' 14.8^{\prime \prime} \mathrm{N}$ \\
\hline 40 & Alsadar-Third 2 & $\mathrm{~K} 40$ & $44^{\circ} 24^{\prime} 31.5 " \mathrm{E}$ & $32^{\circ} 01^{\prime} 03.0^{\prime \prime} \mathrm{N}$ \\
\hline
\end{tabular}




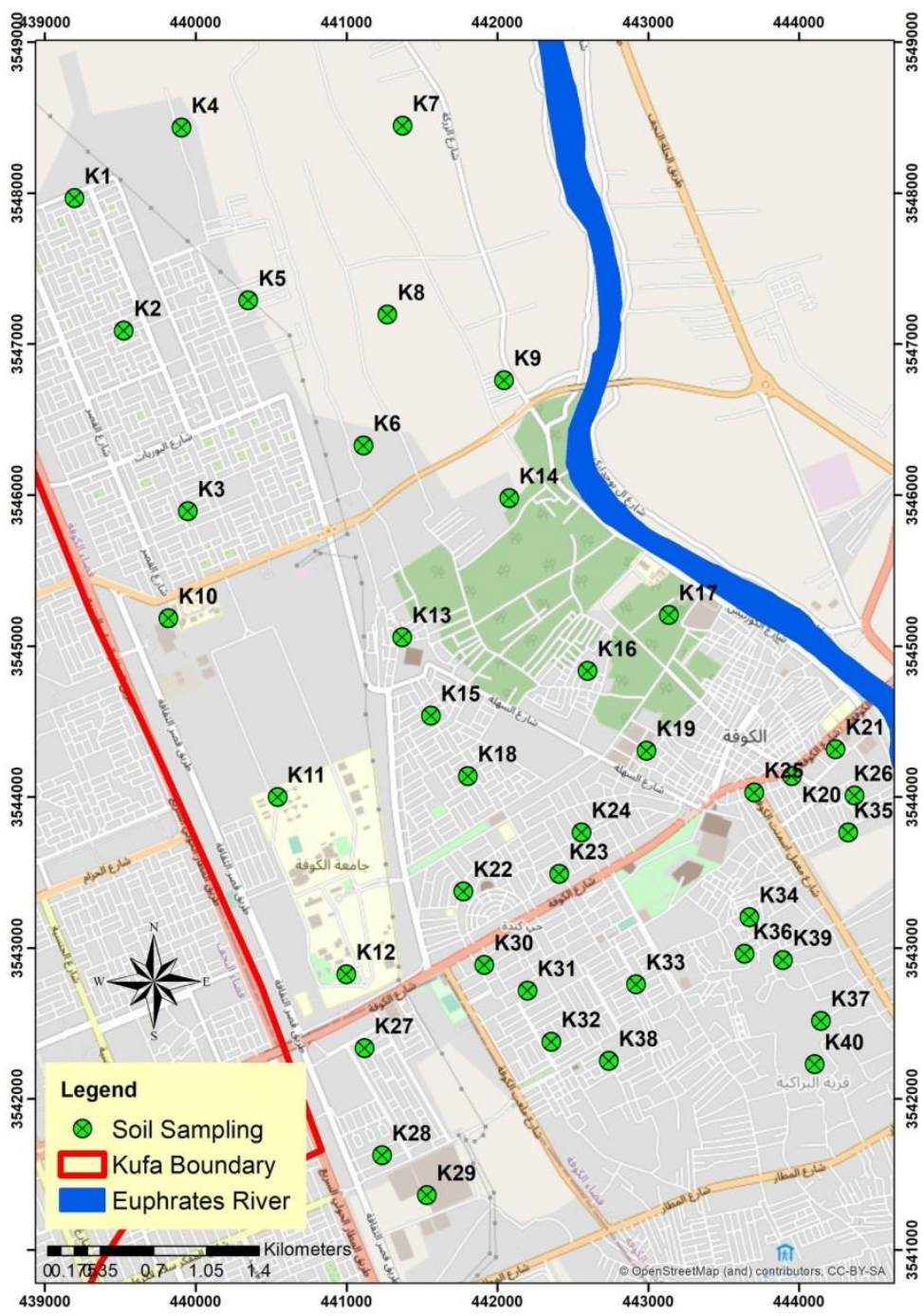

Figure 2. Location of samples in the present study.

\subsection{Preparation of the Samples}

After the collection of soil process was completed, the samples were transferred to the advance of nuclear laboratory at university of Kufa, Faculty of Science, department of Physics for measurements natural radioactivity. There are several the steps in the preparation of samples for the purpose of measurement such as dried, crushed, sieved, stored, and weighted. Grinding the soil sample using a mill after drying in an oven $\left(100^{\circ} \mathrm{C}\right)$ for two hours. Sieve the samples by a 200 sieve $(0.063 \mathrm{~mm})$. Weight $1 \mathrm{~kg}$ of the dried samples and put in bags was Marinelli beaker kept for 30 days to obtain radiation of secular equilibrium [12]. 


\subsection{Gamma-ray Spectroscopy Detection System}

In the present study, the detection system radioisotopes $\left({ }^{238} \mathrm{U},{ }^{232} \mathrm{Th}\right.$, and $\left.{ }^{40} \mathrm{~K}\right)$ was $\mathrm{NaI}(\mathrm{Tl})$ system with a 3"x3" crystal dimension, that made by ORTEC Company (made in USA). These system content many components such as preamplifier, main amplifier, and multi-channel Analyzer (MCA). Also, Maestro-32 software to setting the gain, high voltage, and MCA as well as to determine area under photopeack of gamma spectrum recorded were setup with a PC. The calibration and efficiency for $\mathrm{NaI}$ (TI) detector was determined using five stander sources of radionuclides which is ${ }^{60} \mathrm{Co},{ }^{137} \mathrm{Cs},{ }^{22} \mathrm{Na},{ }^{54} \mathrm{Mn}$, and ${ }^{152} \mathrm{Eu}$. Also, resolution of $\mathrm{NaI}$ (TI) detector for ${ }^{137} \mathrm{Cs}$ were measured which was equal $7.9 \%$. Gamma energies $1764 \mathrm{keV}$ in ${ }^{214} \mathrm{Bi}$ and $2614 \mathrm{keV}$ ${ }^{208} \mathrm{Tl}$ which are in secular equilibrium with ${ }^{238} \mathrm{U}$ and ${ }^{232} \mathrm{Th}$, respectively0, and directly gamma-line of $1460 \mathrm{keV}$ with ${ }^{40} \mathrm{~K}$ were used to measure specific activity in all radionuclides in the present study $[8,10]$.

\subsection{Theoretical calculations}

The specific activities of ${ }^{238} \mathrm{U},{ }^{232} \mathrm{Th}$, and ${ }^{40} \mathrm{~K}\left(\mathrm{~A}_{\mathrm{U}}, \mathrm{A}_{\mathrm{Th}}\right.$ and $\left.\mathrm{A}_{\mathrm{k}}\right)$ radionuclides were calculated using following equation [13]:

$$
A\left(\frac{B q}{k g}\right)=\frac{N}{I_{\gamma} \varepsilon M T}
$$

where, $\mathrm{N}$ is net area under photo peak, $\mathrm{I}_{\gamma}$ is the probability of gamma decay, $\varepsilon$ is the efficiency of detector, $\mathrm{M}$ is the mass of sample, and $\mathrm{T}$ is time measured. But, to calculate specific activity of ${ }^{235} \mathrm{U}$ by [14]:

$$
\mathrm{A}_{235_{\mathrm{U}}}=\frac{\mathrm{A}_{\mathrm{U}}}{21.7}
$$

105 The external hazard index $\left(\mathrm{H}_{\mathrm{ex}}\right)$ was calculated using the following equation [15]:

$$
H_{\text {ex }}=\frac{A_{U}}{370}+\frac{A_{T h}}{259}+\frac{A_{K}}{4810}
$$


107 The internal hazard index $\left(\mathrm{H}_{\mathrm{in}}\right)$ was calculated using the following equation [16]:

108

$$
\mathbf{H}_{\mathrm{in}}=\frac{\mathbf{A}_{\mathrm{U}}}{185}+\frac{\mathbf{A}_{\mathrm{Th}}}{259}+\frac{\mathbf{A}_{\mathrm{K}}}{4810}
$$

109

110

111

112

Representative level index $\left(\mathrm{I}_{\gamma}\right)$ was calculated using the following equation [17].

$$
\mathbf{I}_{\gamma}=\left(\frac{1}{150}\right) \mathbf{A}_{\mathbf{U}}+\left(\frac{1}{100}\right) \mathbf{A}_{\mathrm{Th}}+\left(\frac{1}{1500}\right) \mathbf{A}_{\mathbf{K}}
$$

Alpha index $\left(\mathrm{I}_{\alpha}\right)$ was calculated using the following equation [15]:

$$
I_{\alpha}=\frac{A_{U}}{200\left(\frac{B q}{k g}\right)}
$$

Radium equivalent activity $\left(\mathrm{Ra}_{\mathrm{eq}}\right)$ was calculated using the following equation [18]:

$$
\operatorname{Ra}_{\mathrm{eq}}\left(\frac{\mathrm{Bq}}{\mathrm{kg}}\right)=\mathrm{A}_{\mathrm{U}}+1.43 \mathrm{~A}_{\mathrm{Th}}+0.077 \mathrm{~A}_{\mathrm{K}}
$$

The exposure rate $(\dot{\mathbf{X}})$ was calculated as the following equation $[16,19]$ :

$$
\dot{\mathrm{X}}\left(\frac{\mu R}{h}\right)=1.90 \mathrm{~A}_{\mathrm{U}}+2.82 \mathrm{~A}_{\mathrm{Th}}+0.197 \mathrm{~A}_{\mathrm{K}}
$$

The absorbed dose rate $\left(D_{r}\right)$ in air 1 meter was calculated using the following equation [20]:

$$
D_{r}\left(\frac{n G y}{h}\right)=0.462 A_{U}+0.604 A_{T h}+0.0417 A_{K}
$$

Annual gonadal equivalent dose (AGED) was calculated using the following equation [21- 23] as: 


$$
\operatorname{AEDE}_{\text {indoor }}\left(\frac{\mathrm{mSv}}{\mathrm{y}}\right)=\left[\mathrm{D}_{\mathrm{r}}(\mathrm{mGy} / \mathrm{hr}) \times 8760 \mathrm{hr} \times 0.8 \times 0.7 \mathrm{~Sv} / \mathrm{Gy}\right] \times 10^{-6}
$$

123 Excess lifetime cancer risk (ELCR) indoor according to Duration of Life (DL $=70$ year) and Risk 124 Factor $(\mathrm{RF}=0.05 \mathrm{y} / \mathrm{Sv})$ was calculated using the following equation [13,18 ]:

$$
\text { ELCR }=\text { AEDE } \times \text { DL } \times \text { RF }
$$

\section{Results and Discussions}

The results of specific activity of natural radionuclides $\left({ }^{238} \mathrm{U},{ }^{232} \mathrm{Th}\right.$ and ${ }^{40} \mathrm{~K}$ as well as $\left.{ }^{235} \mathrm{U}\right)$ in soil for Kufa districts were shown in Table 2. While, Table 3 and Table 4 show the results of radiological parameters $\left(\mathrm{Ra}_{\mathrm{eq}}, \mathrm{H}_{\mathrm{ex}}, \mathrm{H}_{\mathrm{in}}, \mathrm{I}_{\gamma}\right.$, and $\left.\mathrm{I}_{\alpha}\right)$ and (Exposure, $\mathrm{D}_{\mathrm{r}}, \mathrm{AGED}, \mathrm{AEDE} \mathrm{Eutdoor}_{\text {, and }}$ ELCR), respectively. The specific activity of uranium-238 in the studied area were ranged from $0.4 \pm 0.1 \mathrm{~Bq} / \mathrm{kg}$ to $17.9 \pm 0.9 \mathrm{~Bq} / \mathrm{kg}$, with an average value $6.2 \pm 0.74$, from $0.2 \pm 0.1 \mathrm{~Bq} / \mathrm{kg}$ to $24.1 \pm 0.6$ $\mathrm{Bq} / \mathrm{kg}$ with an average $6.41 \pm 0.82 \mathrm{~Bq} / \mathrm{kg}$ for thourium-232, from $103.5 \pm 2.0 \mathrm{~Bq} / \mathrm{kg}$ to $708.0 \pm 5.9$ $\mathrm{Bq} / \mathrm{kg}$ with an average value of $278.10 \pm 19.43 \mathrm{~Bq} / \mathrm{kg}$ for potasium-40, while the specific activity of uranium-235 were ranged from $0.018 \pm 0.01 \mathrm{~Bq} / \mathrm{kg}$ to $0.825 \pm 0.08 \mathrm{~Bq} / \mathrm{kg}$ with an average value of $0.28 \pm 0.03 \mathrm{~Bq} / \mathrm{kg}$. The highest value of the specific activity of ${ }^{238} \mathrm{U},{ }^{232} \mathrm{Th}$, and ${ }^{235} \mathrm{U}$ was seen in the K19 sample (Aljamea district), while ${ }^{40} \mathrm{~K}$ was in K17sample (Alsehilia 2 district). The lowest value of the specific activity of ${ }^{238} \mathrm{U},{ }^{232} \mathrm{Th},{ }^{40} \mathrm{~K}$, and ${ }^{235} \mathrm{U}$ was found in samples $\mathrm{K} 10, \mathrm{~K} 26$, K31, and $\mathrm{K} 10$, respectively. Figures 2, 3, and 4 obtain histograms of the specific activities for the frequency distribution of uranium-238, thorium-232, and potasium-40, respectively. Histograms were divided into nine parts in terms of specific activity values. From figure 2 , the maximum value of specific activity for uranium-238 in second groups, while for thorium-232 the high value was in first group as shown in figure 3, and from figure 4, five group was high value of specific activity for potasium40. Figure 5, showing the distribution compering of radioactive isotopes of uranium-238, thorium232, and potassium-40 in the soil of the present study which appeared varied in the quantity of these radionuclides. Also, it is found that Potassium-40 predominant on uranium-238 and thorium-232, 
146 but the average quantity of thorium-232 is almost larger than the quantity of uranium-238 in the 147 study area. The difference between concentrations ${ }^{238} \mathrm{U}$ and ${ }^{232} \mathrm{Th}$ indicates the minimum 148 contribution of monazite minerals in the samples. The values are almost less than unity because $149{ }^{232} \mathrm{Th}$ activities are usually greater than ${ }^{238} \mathrm{U}$ activities in the crust, which is the origin of the soil. 150 These variations may be because uranium and thorium decay series come from different origins and 151 exist together in nature, whereas potassium is from a different origin $[10,25]$. While, the highest 152 distribution of potassium-40 may be because of the increase in the concentration of potassium 153 nuclide in some areas, the reason is due to the existence of agricultural land and areas containing 154 phosphate fertilizers, in which the focus increasingly peer-potassium $\left({ }^{40} \mathrm{~K}\right)$. The average values of 155 the specific activity of ${ }^{238} \mathrm{U},{ }^{232} \mathrm{Th}$, and ${ }^{40} \mathrm{~K}$ according to recommendations by UNSCEAR 2008 156 were $33 \mathrm{~Bq} / \mathrm{kg}, 45 \mathrm{~Bq} / \mathrm{kg}$, and $420 \mathrm{~Bq} / \mathrm{kg}$ respectively [20]. Therefore, the specific activity of ${ }^{238} \mathrm{U}$ 157 and ${ }^{232}$ Th that shown in table 2 in all location sites were within UNSCEAR 2008, while samples $158 \mathrm{~K} 15$, K16, and $\mathrm{K} 17$ have the specific activity of ${ }^{40} \mathrm{~K}$ larger than the world average activity that was recommended by UNSCEAR 2008. Distribution a map (color contour map) of the specific activities in unit of $\mathrm{Bq} / \mathrm{kg}$ for radioisotopes ${ }^{238} \mathrm{U},{ }^{232} \mathrm{Th},{ }^{40} \mathrm{~K}$, and ${ }^{235} \mathrm{U}$ in all soil samples of the present study was shown in Figures 6, 7, 8, and 9, respectively which it is drawn by geographic information system (GIS) technology. 
Table 2. The specific activity for natural radioactivity in soil for Kufa districts

\begin{tabular}{|c|c|c|c|c|c|c|c|c|c|}
\hline \multirow{3}{*}{ No. } & \multirow{3}{*}{$\begin{array}{c}\text { Sample } \\
\text { code }\end{array}$} & \multicolumn{8}{|c|}{ Specific Activity (Bq/kg) } \\
\hline & & \multicolumn{2}{|c|}{${ }^{238} \mathrm{U}$} & \multicolumn{2}{|c|}{${ }^{232} \mathrm{Th}$} & \multicolumn{2}{|c|}{${ }^{40} \mathrm{~K}$} & \multicolumn{2}{|c|}{${ }^{235} \mathrm{U}$} \\
\hline & & Average & \pm S.E & Average & \pm S.E & Average & \pm S.E & Average & \pm S.E \\
\hline 1 & $\mathrm{k} 1$ & 5.3 & 0.5 & 1.3 & 0.1 & 109.9 & 2.2 & 0.244 & 0.04 \\
\hline 2 & $\mathrm{k} 2$ & 4.9 & 0.5 & 1.2 & 0.1 & 142.4 & 2.5 & 0.226 & 0.04 \\
\hline 3 & k3 & 2.3 & 0.3 & 0.7 & 0.1 & 145.4 & 2.5 & 0.106 & 0.03 \\
\hline 4 & $\mathrm{k} 4$ & 2.9 & 0.3 & 2.2 & 0.2 & 176.4 & 2.7 & 0.134 & 0.03 \\
\hline 5 & $\mathrm{k} 5$ & 2.8 & 0.3 & 1.4 & 0.2 & 150.0 & 2.6 & 0.129 & 0.03 \\
\hline 6 & k6 & 5.4 & 0.5 & 6.2 & 0.3 & 130.7 & 2.5 & 0.249 & 0.04 \\
\hline 7 & k7 & 1 & 0.2 & 6.9 & 0.4 & 303.0 & 4.0 & 0.046 & 0.02 \\
\hline 8 & $\mathrm{k} 8$ & 1.1 & 0.2 & 1.5 & 0.1 & 184.3 & 2.7 & 0.051 & 0.02 \\
\hline 9 & k9 & 9.1 & 0.6 & 1 & 0.1 & 226.5 & 3.3 & 0.419 & 0.06 \\
\hline 10 & k10 & 0.4 & 0.1 & 2.2 & 0.2 & 210.1 & 3.0 & 0.018 & 0.01 \\
\hline 11 & k11 & 0.9 & 0.2 & 3.1 & 0.2 & 167.2 & 2.8 & 0.041 & 0.02 \\
\hline 12 & $\mathrm{k} 12$ & 6.9 & 0.5 & 15.3 & 0.5 & 336.8 & 4.0 & 0.318 & 0.05 \\
\hline 13 & k13 & 6.6 & 0.6 & 6.7 & 0.3 & 339.3 & 4.1 & 0.304 & 0.05 \\
\hline 14 & k14 & 3.3 & 0.3 & 1.6 & 0.1 & 109.0 & 2.1 & 0.152 & 0.03 \\
\hline 15 & $\mathrm{k} 15$ & 4.5 & 0.5 & 13.6 & 0.5 & 443.3 & 4.7 & 0.207 & 0.04 \\
\hline 16 & k16 & 2.1 & 0.3 & 6.4 & 0.3 & 537.0 & 5.1 & 0.097 & 0.03 \\
\hline 17 & k17 & 7.6 & 0.6 & 13.2 & 0.5 & 708.0 & 5.9 & 0.350 & 0.05 \\
\hline 18 & $\mathrm{k} 18$ & 14.1 & 0.8 & 12.5 & 0.4 & 113.8 & 2.3 & 0.650 & 0.07 \\
\hline 19 & k19 & 17.9 & 0.9 & 24.1 & 0.6 & 389.8 & 4.4 & 0.825 & 0.08 \\
\hline 20 & k20 & 11.4 & 0.7 & 9.1 & 0.4 & 303.1 & 3.7 & 0.525 & 0.06 \\
\hline 21 & $\mathrm{k} 21$ & 1.2 & 0.2 & 1.4 & 0.1 & 229.3 & 3.1 & 0.055 & 0.02 \\
\hline
\end{tabular}




\begin{tabular}{|c|c|c|c|c|c|c|c|c|c|}
\hline 22 & $\mathrm{k} 22$ & 13.1 & 0.8 & 8.5 & 0.4 & 316.7 & 3.9 & 0.604 & 0.07 \\
\hline 23 & $\mathrm{k} 23$ & 8.4 & 0.6 & 10 & 0.4 & 317.9 & 3.8 & 0.387 & 0.05 \\
\hline 24 & $\mathrm{k} 24$ & 10.2 & 0.7 & 11.3 & 0.4 & 307.8 & 3.8 & 0.470 & 0.06 \\
\hline 25 & $\mathrm{k} 25$ & 5.8 & 0.5 & 15.4 & 0.5 & 396.5 & 4.5 & 0.267 & 0.05 \\
\hline 26 & $\mathrm{k} 26$ & 0.91 & 0.2 & 0.2 & 0.1 & 181.6 & 2.9 & 0.041 & 0.02 \\
\hline 27 & $\mathrm{k} 27$ & 14.2 & 0.8 & 8.5 & 0.4 & 279.0 & 3.6 & 0.654 & 0.07 \\
\hline 28 & $\mathrm{k} 28$ & 2.4 & 0.3 & 6.6 & 0.3 & 395.3 & 3.9 & 0.111 & 0.03 \\
\hline 29 & $\mathrm{k} 29$ & 14.1 & 0.8 & 9.1 & 0.4 & 320.6 & 3.9 & 0.650 & 0.07 \\
\hline 30 & $\mathrm{k} 30$ & 8.4 & 0.6 & 2.9 & 0.2 & 333.1 & 4.0 & 0.387 & 0.05 \\
\hline 31 & $\mathrm{k} 31$ & 1.7 & 0.2 & 1.5 & 0.1 & 103.5 & 2.0 & 0.078 & 0.02 \\
\hline 32 & $\mathrm{k} 32$ & 13.2 & 0.7 & 6.8 & 0.3 & 300.8 & 3.7 & 0.608 & 0.07 \\
\hline 33 & $\mathrm{k} 33$ & 3.5 & 0.4 & 8.4 & 0.4 & 292.2 & 3.7 & 0.161 & 0.04 \\
\hline 34 & $\mathrm{k} 34$ & 1.4 & 0.2 & 8.1 & 0.4 & 425.9 & 4.6 & 0.065 & 0.02 \\
\hline 35 & $\mathrm{k} 35$ & 3.2 & 0.4 & 5.7 & 0.3 & 283.9 & 3.7 & 0.147 & 0.03 \\
\hline 36 & $\mathrm{k} 36$ & 2.4 & 0.3 & 5.8 & 0.3 & 312.5 & 3.3 & 0.111 & 0.03 \\
\hline 37 & $\mathrm{k} 37$ & 6.4 & 0.5 & 2.2 & 0.2 & 241.1 & 3.0 & 0.295 & 0.05 \\
\hline 38 & $\mathrm{k} 38$ & 6.5 & 0.6 & 3.9 & 0.3 & 299.3 & 3.9 & 0.300 & 0.05 \\
\hline 38 & k39 & 5 & 0.5 & 0.6 & 0.1 & 238.8 & 3.4 & 0.230 & 0.04 \\
\hline 40 & $\mathrm{k} 40$ & 15.5 & 0.9 & 9.6 & 0.4 & 322.3 & 4.2 & 0.714 & 0.07 \\
\hline \multicolumn{2}{|c|}{ Average \pm S.D } & \multicolumn{2}{|c|}{$6.2 \pm 0.74$} & \multicolumn{2}{|c|}{$6.41 \pm 0.82$} & \multicolumn{2}{|c|}{$278.10 \pm 19.43$} & \multicolumn{2}{|c|}{$0.28 \pm 0.03$} \\
\hline
\end{tabular}


Uranium-238

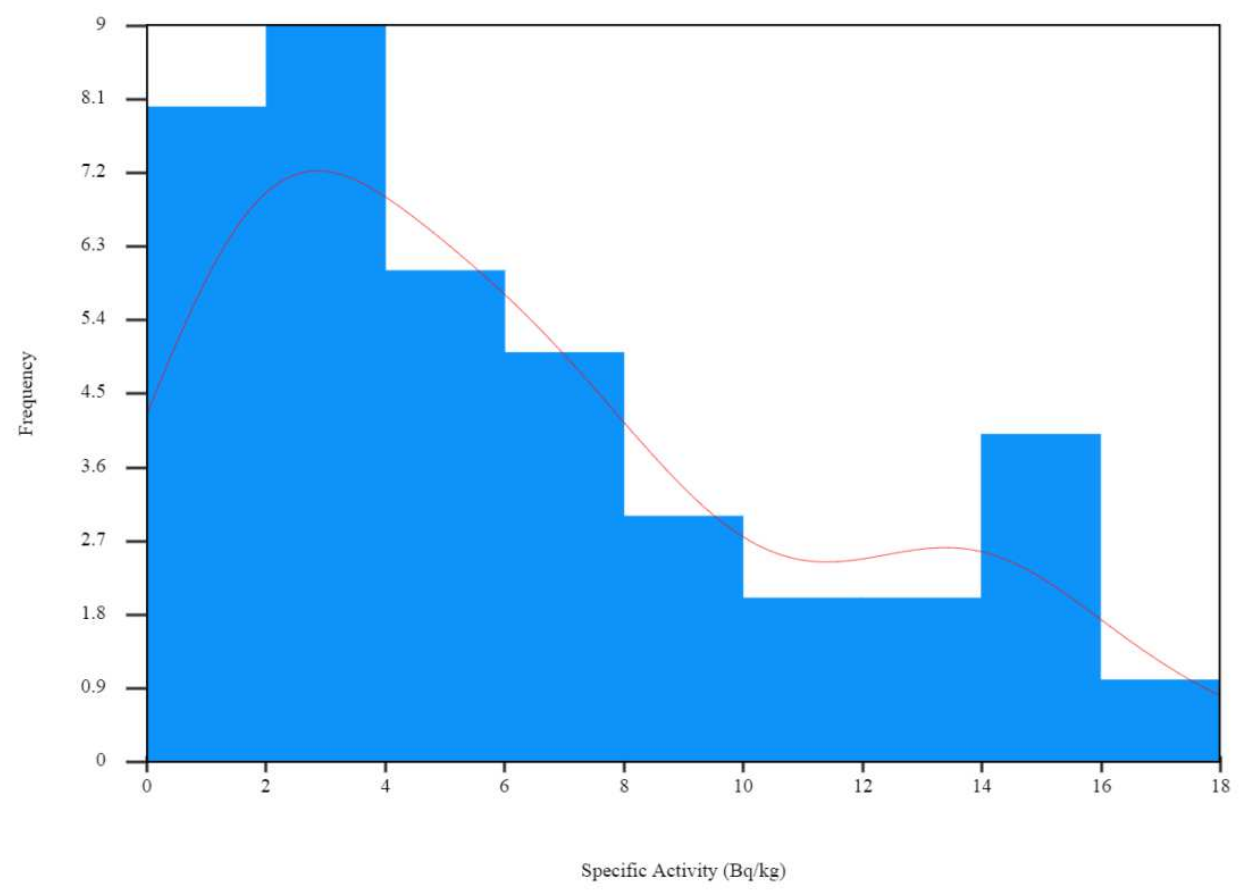

Figure 2. Histograms of specific activities for ${ }^{238} \mathrm{U}$ in soil of present study.

Thourium-232

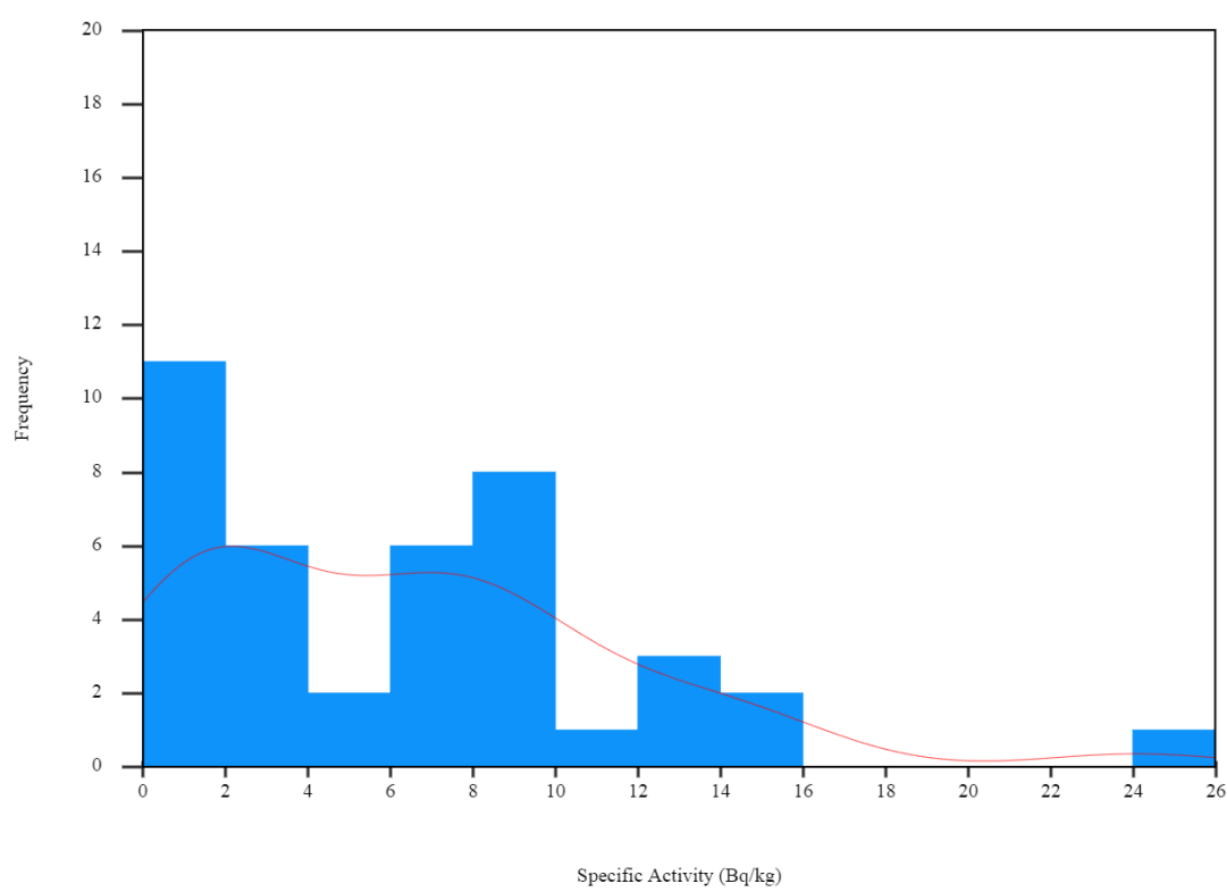

Figure 3. Histograms of specific activities for ${ }^{232} \mathrm{Th}$ in soil of present study. 
Potasium-40

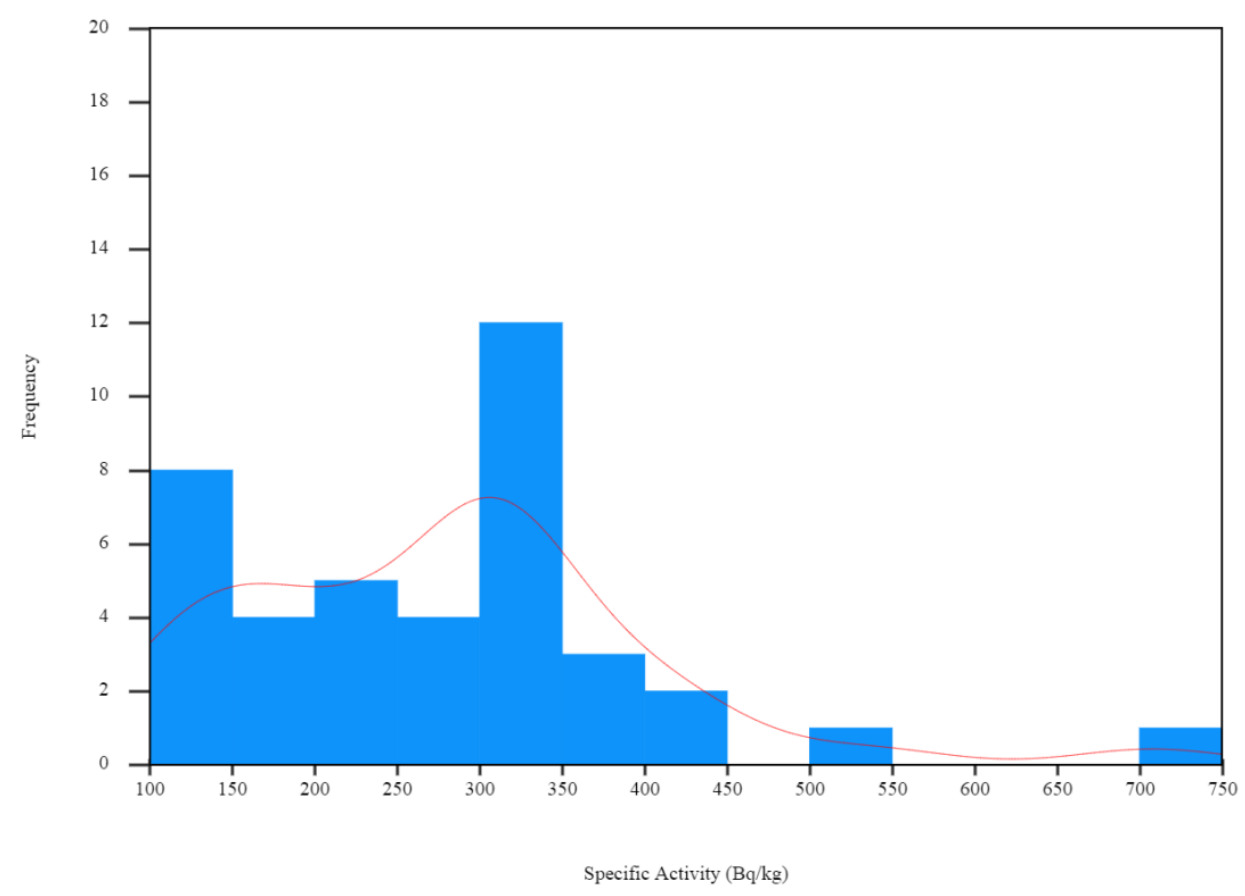

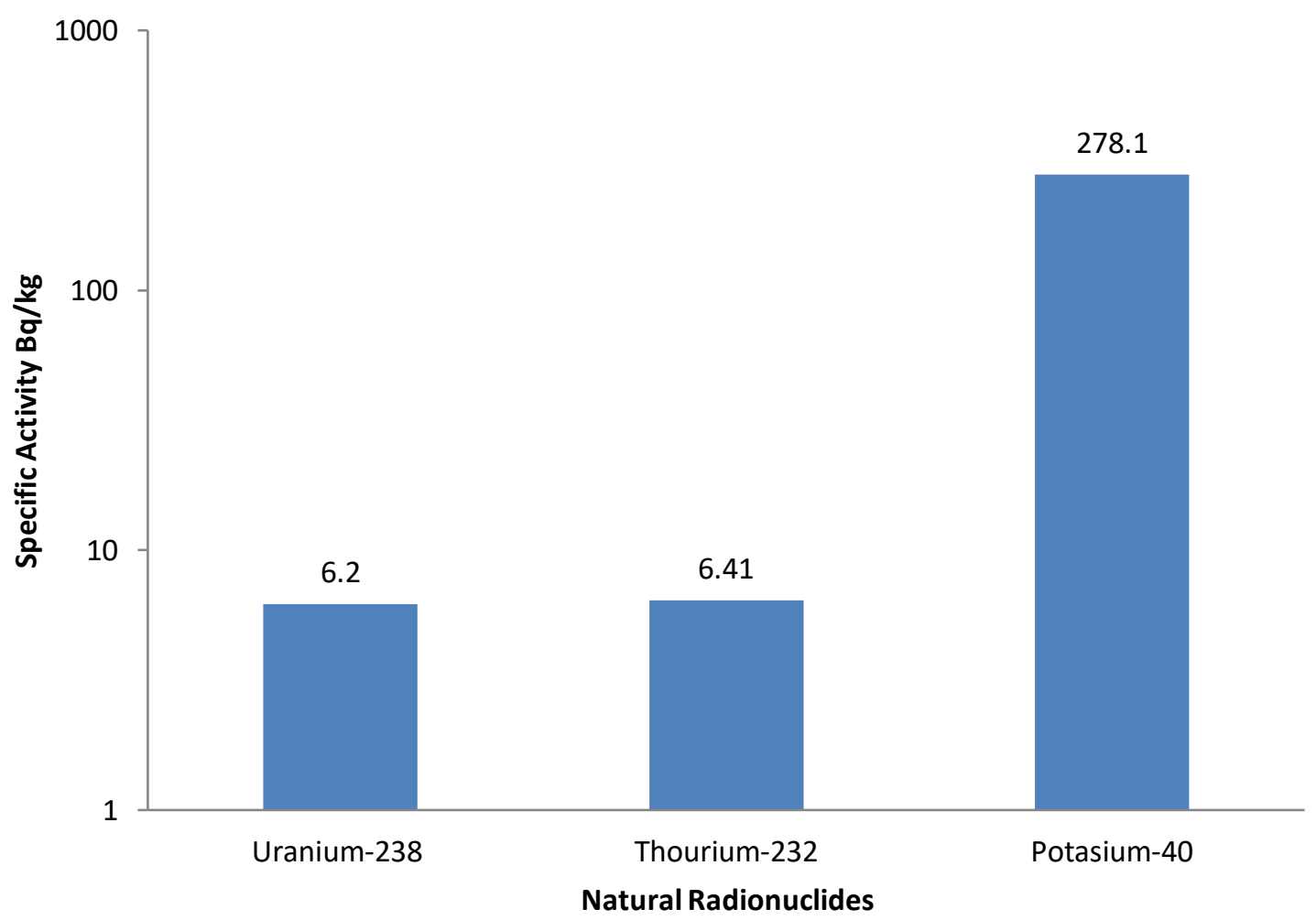




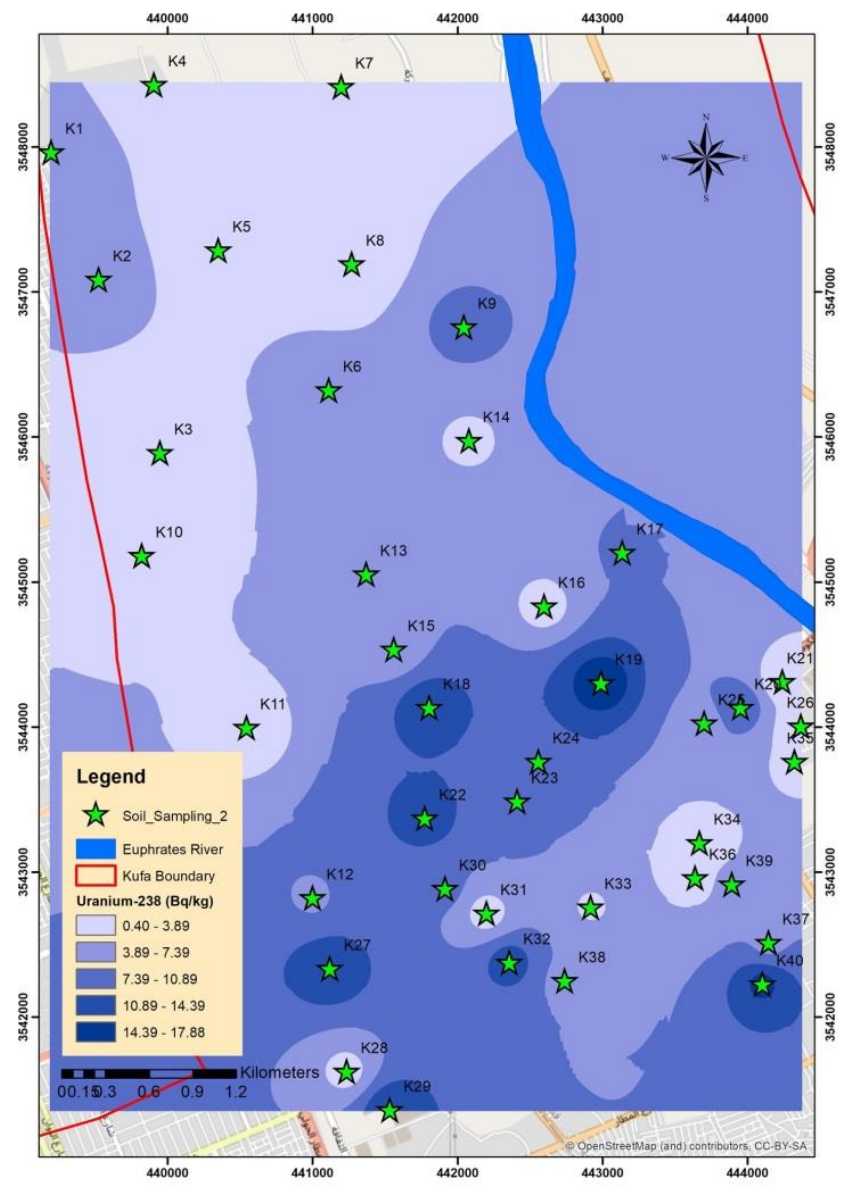

Figure 6. Distribution of ${ }^{238} \mathrm{U}$ in soil of study area.

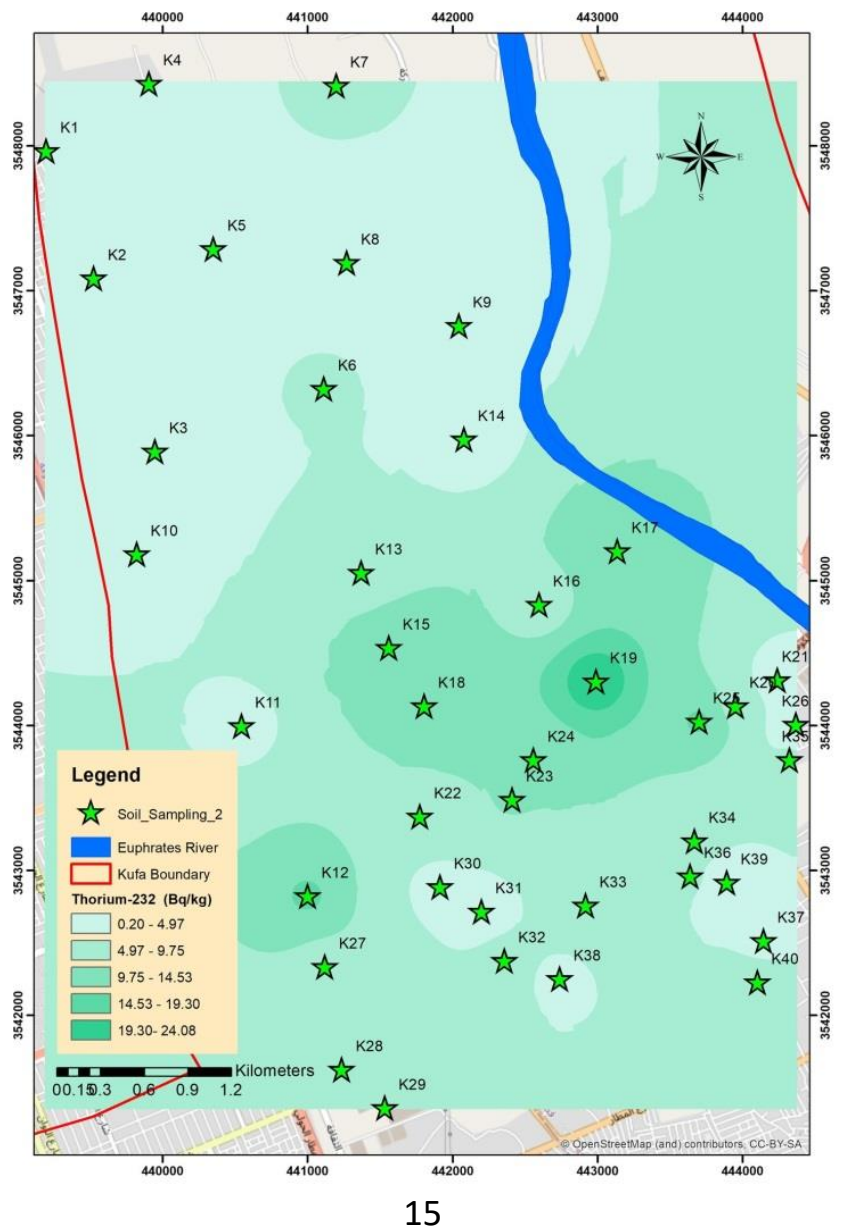


Figure 7. Distribution of ${ }^{232} \mathrm{Th}$ in soil of study area.

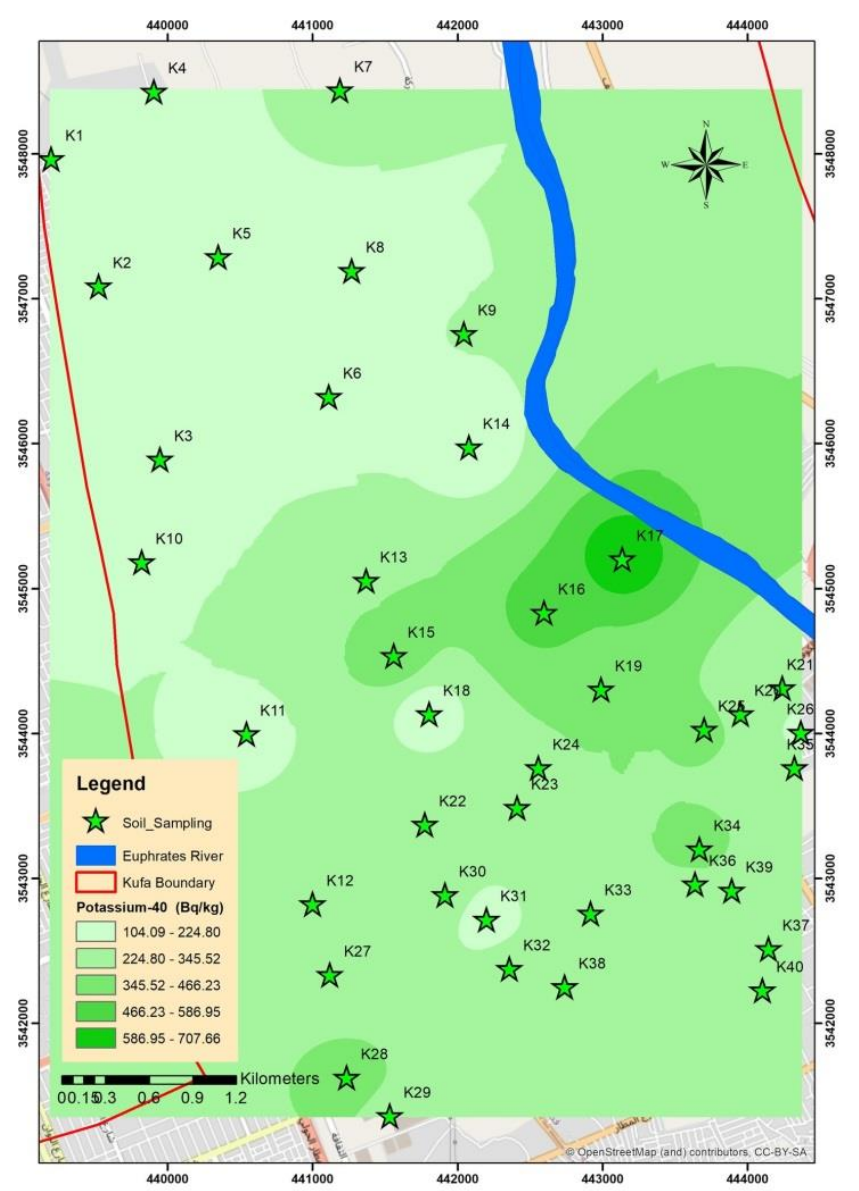

Figure 8. Distribution of ${ }^{40} \mathrm{~K}$ in soil of study area. 


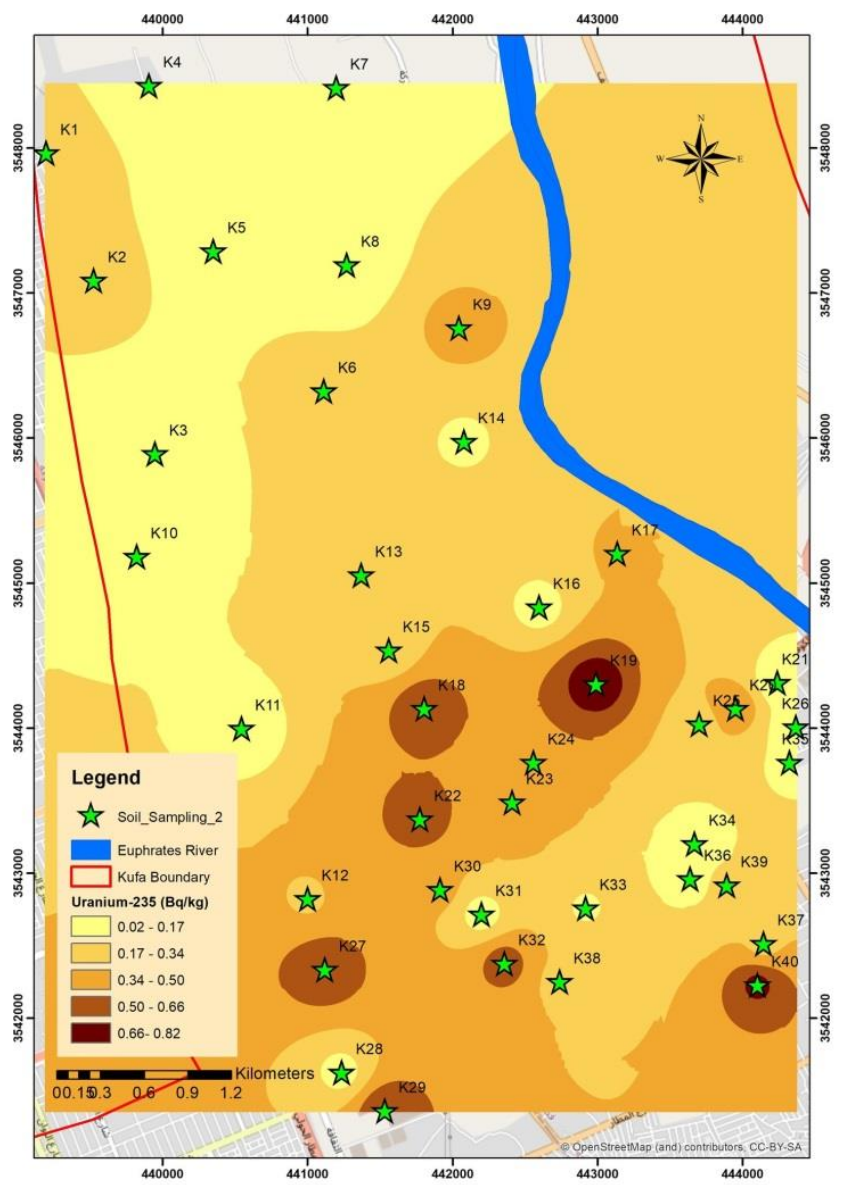

Figure 9. Distribution of ${ }^{235} \mathrm{U}$ in soil of study area.

The results of $\mathrm{Ra}_{\mathrm{eq}}$ were ranged from $11.8 \mathrm{~Bq} / \mathrm{kg}$ to $82.4 \mathrm{~Bq} / \mathrm{kg}$, with an average value of $36.79 \pm 2.78 \mathrm{~Bq} / \mathrm{kg}$, also it is found the minimum and the maximum values of $\mathrm{H}_{\mathrm{ex}}, \mathrm{H}_{\mathrm{in}}, \mathrm{I}_{\gamma}$, and $\mathrm{I}_{\alpha}$ in the same sample $\mathrm{K} 31$ and $\mathrm{K} 19$, as shown in Table 3. The values of $\mathrm{H}_{\mathrm{ex}}$ and $\mathrm{H}_{\mathrm{in}}$ were ranged from 0.032 to 0.222 , with an average of $0.099 \pm 0.007$, and from 0.036 to 0.271 , with an average of $0.116 \pm 0.008$, respectively. While the results of other parameters such as $\mathrm{I}_{\gamma}$, and $\mathrm{I}_{\alpha}$ were ranged from 0.095 to 0.655 , with an average of $0.290 \pm 0.021$, and from 0.009 to 0.090 , with an average of $0.031 \pm 0.003$, respectively. The minimum value of all radiological parameters that shown in Table 3 was in samples K31 (Kenda 2), while, the maximum was found in samples K19 (Aljamea), except value of $\mathrm{I}_{\gamma}$ the maximum was in samples $\mathrm{K} 17$ (Alsehilia 2). From the results of radiological parameters $\left(\mathrm{Ra}_{\mathrm{eq}}, \mathrm{H}_{\mathrm{ex}}, \mathrm{H}_{\mathrm{in}}, \mathrm{I}_{\gamma}\right.$, and $\left.\mathrm{I}_{\alpha}\right)$ in Table 2 for all soil samples under study were less than 370 $\mathrm{Bq} / \mathrm{kg}$ for $\mathrm{R}_{\mathrm{aeq}}$ [26] and less than unity for the values of $\mathrm{H}_{\mathrm{ex}}, \mathrm{H}_{\mathrm{in}}, \mathrm{I}_{\gamma}$, and $\mathrm{I}_{\alpha}$ [27]. The distribution of a 
202 map (color contour map) of $\mathrm{Ra}_{\mathrm{eq}}$ and $\mathrm{H}_{\mathrm{ex}}$ due to radioisotopes ${ }^{238} \mathrm{U},{ }^{232} \mathrm{Th}$, and ${ }^{40} \mathrm{~K}$ in all soil 203 samples of the present study was shown in Figures 10, and 11, respectively which is drawn by 204 geographic information system (GIS) technology.

205 Table 3. The radiological parameters ( $R \mathbf{a}_{\mathrm{eq}}, \mathbf{H}_{\mathrm{ex}}, \mathbf{H}_{\mathrm{in}}, \mathbf{I}_{\gamma}$, and $\left.\mathbf{I}_{\alpha}\right)$ for nature radioactivity in soil 206 for Kufa districts

\begin{tabular}{|c|c|c|c|c|c|c|}
\hline No. & Sample code & $\operatorname{Ra}_{\mathrm{eq}}(\mathrm{Bq} / \mathrm{kg})$ & $\mathbf{H}_{\mathbf{e x}}$ & $\mathbf{H}_{\text {in }}$ & $\overline{\mathbf{I}_{\gamma}}$ & $\mathbf{I}_{\alpha}$ \\
\hline 1 & $\mathrm{k} 1$ & 15.6 & 0.042 & 0.057 & 0.122 & 0.027 \\
\hline 2 & $\mathrm{k} 2$ & 17.6 & 0.047 & 0.061 & 0.140 & 0.025 \\
\hline 3 & $\mathrm{k} 3$ & 14.5 & 0.039 & 0.045 & 0.119 & 0.012 \\
\hline 4 & $\mathrm{k} 4$ & 19.6 & 0.053 & 0.061 & 0.159 & 0.015 \\
\hline 5 & $\mathrm{k} 5$ & 16.4 & 0.044 & 0.052 & 0.133 & 0.014 \\
\hline 6 & k6 & 24.3 & 0.066 & 0.080 & 0.185 & 0.027 \\
\hline 7 & k7 & 34.2 & 0.092 & 0.095 & 0.278 & 0.005 \\
\hline 8 & $\mathrm{k} 8$ & 17.4 & 0.047 & 0.050 & 0.145 & 0.006 \\
\hline 9 & k9 & 28.0 & 0.076 & 0.100 & 0.222 & 0.046 \\
\hline 10 & k10 & 19.7 & 0.053 & 0.054 & 0.165 & 0.002 \\
\hline 11 & $\mathrm{k} 11$ & 18.2 & 0.049 & 0.052 & 0.148 & 0.005 \\
\hline 12 & $\mathrm{k} 12$ & 54.7 & 0.148 & 0.166 & 0.424 & 0.035 \\
\hline 13 & k13 & 42.3 & 0.114 & 0.132 & 0.337 & 0.033 \\
\hline 14 & k14 & 14.0 & 0.038 & 0.047 & 0.111 & 0.017 \\
\hline 15 & $\mathrm{k} 15$ & 58.1 & 0.157 & 0.169 & 0.462 & 0.023 \\
\hline 16 & k16 & 52.6 & 0.142 & 0.148 & 0.436 & 0.011 \\
\hline 17 & $\mathrm{k} 17$ & 81.0 & 0.219 & 0.239 & 0.655 & 0.038 \\
\hline 18 & $\mathrm{k} 18$ & 40.7 & 0.110 & 0.148 & 0.295 & 0.071 \\
\hline 19 & k19 & 82.4 & 0.222 & 0.271 & 0.620 & 0.090 \\
\hline
\end{tabular}




\begin{tabular}{|c|c|c|c|c|c|c|}
\hline 20 & $\mathrm{k} 20$ & 47.8 & 0.129 & 0.160 & 0.369 & 0.057 \\
\hline 21 & $\mathrm{k} 21$ & 20.9 & 0.056 & 0.060 & 0.175 & 0.006 \\
\hline 22 & $\mathrm{k} 22$ & 49.6 & 0.134 & 0.169 & 0.383 & 0.066 \\
\hline 23 & $\mathrm{k} 23$ & 47.2 & 0.127 & 0.150 & 0.368 & 0.042 \\
\hline 24 & $\mathrm{k} 24$ & 50.1 & 0.135 & 0.163 & 0.386 & 0.051 \\
\hline 25 & $\mathrm{k} 25$ & 58.4 & 0.158 & 0.173 & 0.457 & 0.029 \\
\hline 26 & k26 & 15.2 & 0.041 & 0.043 & 0.129 & 0.005 \\
\hline 27 & $\mathrm{k} 27$ & 47.8 & 0.129 & 0.168 & 0.366 & 0.071 \\
\hline 28 & $\mathrm{k} 28$ & 42.3 & 0.114 & 0.121 & 0.346 & 0.012 \\
\hline 29 & $\mathrm{k} 29$ & 51.8 & 0.140 & 0.178 & 0.399 & 0.071 \\
\hline 30 & $\mathrm{k} 30$ & 38.2 & 0.103 & 0.126 & 0.307 & 0.042 \\
\hline 31 & $\mathrm{k} 31$ & 11.8 & 0.032 & 0.036 & 0.095 & 0.009 \\
\hline 32 & $\mathrm{k} 32$ & 46.1 & 0.124 & 0.160 & 0.357 & 0.066 \\
\hline 33 & $\mathrm{k} 33$ & 38.0 & 0.103 & 0.112 & 0.302 & 0.018 \\
\hline 34 & $\mathrm{k} 34$ & 45.8 & 0.124 & 0.127 & 0.374 & 0.007 \\
\hline 35 & $\mathrm{k} 35$ & 33.2 & 0.090 & 0.098 & 0.268 & 0.016 \\
\hline 36 & $\mathrm{k} 36$ & 34.8 & 0.094 & 0.100 & 0.282 & 0.012 \\
\hline 37 & $\mathrm{k} 37$ & 28.1 & 0.076 & 0.093 & 0.225 & 0.032 \\
\hline 38 & $\mathrm{k} 38$ & 35.1 & 0.095 & 0.112 & 0.282 & 0.033 \\
\hline 38 & k39 & 24.2 & 0.065 & 0.079 & 0.199 & 0.025 \\
\hline 40 & $\mathrm{k} 40$ & 54.0 & 0.146 & 0.188 & 0.414 & 0.078 \\
\hline \multicolumn{2}{|c|}{ Average \pm S.E. } & $36.79 \pm 2.78$ & $0.099 \pm 0.007$ & $0.116 \pm 0.008$ & $0.290 \pm 0.021$ & $0.031 \pm 0.003$ \\
\hline
\end{tabular}




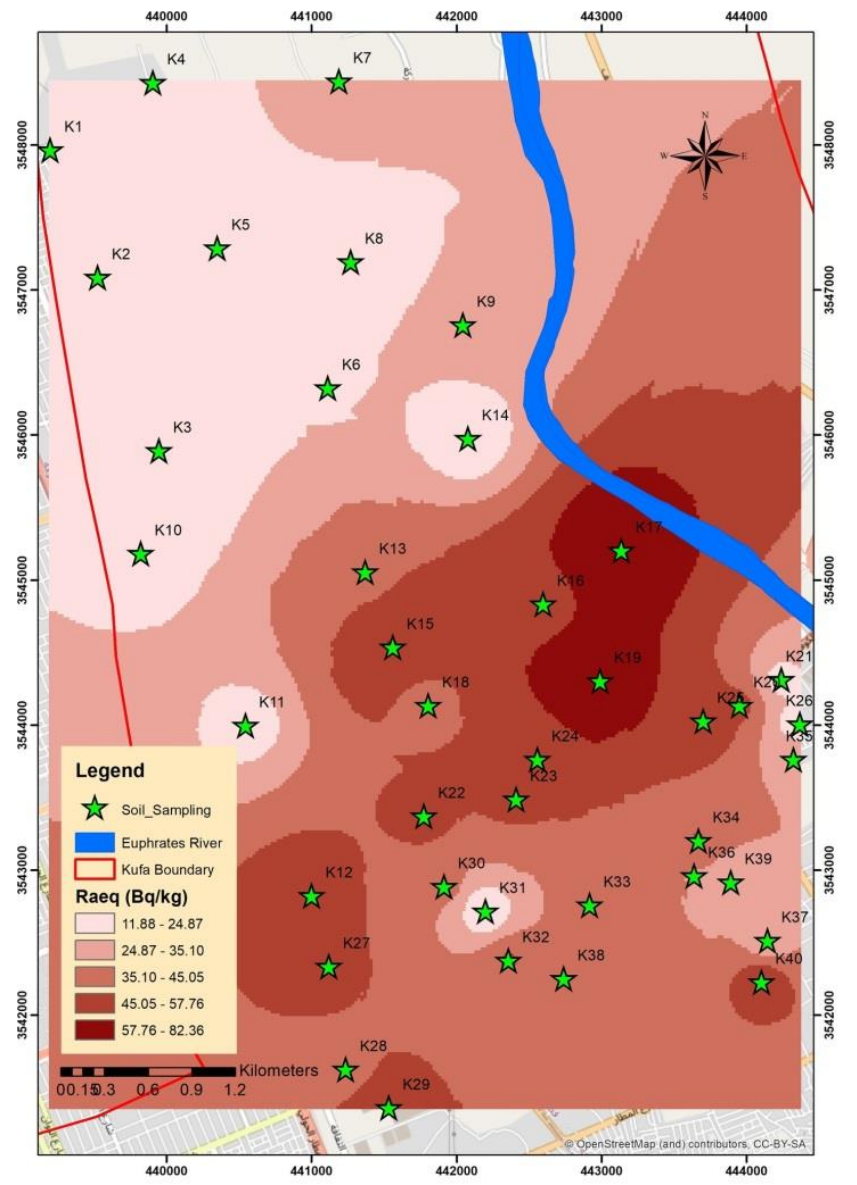

Figure 10. Distribution of $\mathbf{R a}_{\mathrm{eq}}$ in soil of study area.

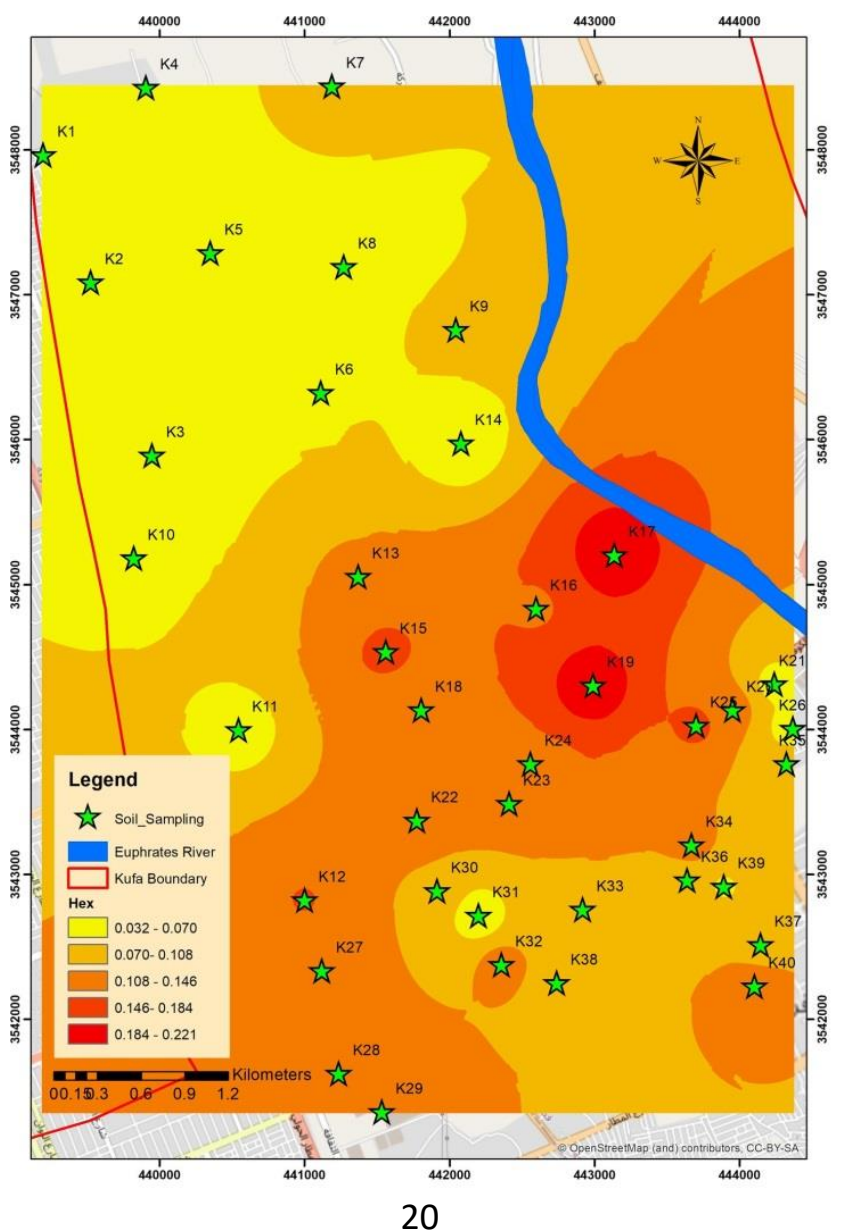


The results of another radiological parameters that shown in Table 4, Exposure was ranged 214 from $27.8 \mu R / h$ to $191.1 \mu R / h$, with an average value of $84.66 \pm 6.21 \mu R / h$, the values of $D_{\text {r }}$ were 215 ranged from $6.0 \mathrm{nGy} / \mathrm{h}$ to $41.0 \mathrm{nGy} / \mathrm{h}$, with an average value of $18.33 \pm 1.34 \mathrm{nGy} / \mathrm{h}$. While the results

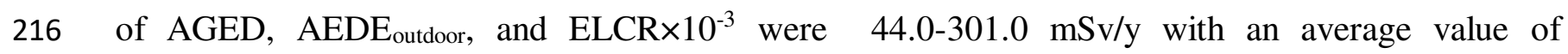
$217133.301 \pm 9.70,0.007-0.050 \mathrm{mSv} / \mathrm{y}$ with an average value of $0.022 \pm 0.001 \mathrm{mSv} / \mathrm{y}$, and $0.026-0.176$ 218 with an average value of $0.078 \pm 0.005$, respectively. The minimum value of all radiological

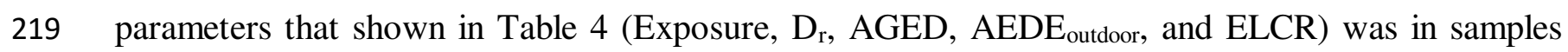
$220 \mathrm{~K} 31$ (Kenda 2), while, the maximum was found in samples K17 (Alsehilia 2). The results of $\mathrm{D}_{\mathrm{r}}$ inunit $\mathrm{nGy} / \mathrm{h}$ in Table 3 for all of the soil samples studied were less than the world average value that equal $55 \mathrm{nGy} / \mathrm{h}$ [28]. Also, it noted that the results of AGED in-unit mSv/y were lower than the global average value that equal 55 [28, 29], except sample K17, which was higher than the limit

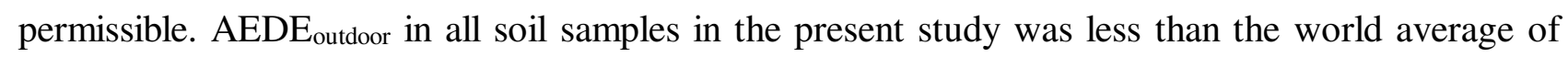
$0.07 \mathrm{mSv} / \mathrm{y}$ [29]. The results of ELCR in all location samples were lower when compared with the world average permissible limit of $0.29 \times 10^{-3}$ [28], which was shown in the map of Figure 12 , as shown in the map in bold color, the highest value was in the area of sample K17 and K19 in the map of dark color. 


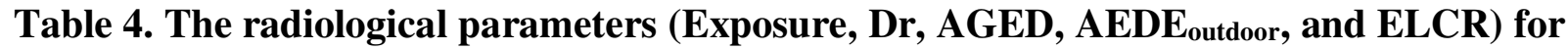

nature radioactivity in soil for Kufa districts

\begin{tabular}{|c|c|c|c|c|c|c|}
\hline No. & $\begin{array}{c}\text { Sample } \\
\text { code }\end{array}$ & $\begin{array}{c}\text { Exposure } \\
(\mu \mathrm{R} / \mathrm{h})\end{array}$ & $\begin{array}{c}\text { Dr } \\
(\mathrm{nGy} / \mathrm{h})\end{array}$ & $\begin{array}{l}\text { AGED } \\
(\mathrm{mSv} / \mathrm{y})\end{array}$ & $\begin{array}{c}\text { AEDE }_{\text {outdoor }} \\
(\mathrm{mSv} / \mathrm{y})\end{array}$ & ELCR $\times 10^{-3}$ \\
\hline 1 & $\mathrm{k} 1$ & 35.4 & 7.8 & 56.3 & 0.010 & 0.034 \\
\hline 2 & $\mathrm{k} 2$ & 40.7 & 8.9 & 64.9 & 0.011 & 0.038 \\
\hline 3 & k3 & 35.0 & 7.5 & 55.7 & 0.009 & 0.032 \\
\hline 4 & $\mathrm{k} 4$ & 46.5 & 10.0 & 73.5 & 0.012 & 0.043 \\
\hline 5 & $\mathrm{k} 5$ & 38.8 & 8.4 & 61.6 & 0.010 & 0.036 \\
\hline 6 & k6 & 53.5 & 11.7 & 83.6 & 0.014 & 0.050 \\
\hline 7 & k7 & 81.0 & 17.3 & 127.1 & 0.021 & 0.074 \\
\hline 8 & $\mathrm{k} 8$ & 42.6 & 9.1 & 67.5 & 0.011 & 0.039 \\
\hline 9 & $\mathrm{k} 9$ & 64.7 & 14.3 & 103.4 & 0.017 & 0.061 \\
\hline 10 & k10 & 48.4 & 10.3 & 76.4 & 0.013 & 0.044 \\
\hline 11 & $\mathrm{k} 11$ & 43.4 & 9.3 & 68.2 & 0.011 & 0.040 \\
\hline 12 & k12 & 122.6 & 26.5 & 191.0 & 0.032 & 0.114 \\
\hline 13 & k13 & 98.3 & 21.2 & 154.9 & 0.026 & 0.091 \\
\hline 14 & k14 & 32.3 & 7.0 & 51.1 & 0.009 & 0.030 \\
\hline 15 & k15 & 134.2 & 28.8 & 209.9 & 0.035 & 0.124 \\
\hline 16 & k16 & 127.8 & 27.2 & 201.9 & 0.033 & 0.117 \\
\hline 17 & k17 & 191.1 & 41.0 & 301.0 & 0.050 & 0.176 \\
\hline 18 & k18 & 84.5 & 18.8 & 131.6 & 0.023 & 0.081 \\
\hline 19 & k19 & 178.8 & 39.1 & 278.4 & 0.048 & 0.168 \\
\hline 20 & k20 & 107.0 & 23.4 & 168.4 & 0.029 & 0.100 \\
\hline 21 & k21 & 51.4 & 11.0 & 81.6 & 0.013 & 0.047 \\
\hline
\end{tabular}




\begin{tabular}{|c|c|c|c|c|c|c|}
\hline 22 & $\mathrm{k} 22$ & 111.2 & 24.4 & 175.5 & 0.030 & 0.105 \\
\hline 23 & $\mathrm{k} 23$ & 106.8 & 23.2 & 167.6 & 0.028 & 0.099 \\
\hline 24 & $\mathrm{k} 24$ & 111.9 & 24.4 & 175.4 & 0.030 & 0.105 \\
\hline 25 & $\mathrm{k} 25$ & 132.6 & 28.5 & 206.8 & 0.035 & 0.122 \\
\hline 26 & $\mathrm{k} 26$ & 38.0 & 8.1 & 60.6 & 0.010 & 0.035 \\
\hline 27 & $\mathrm{k} 27$ & 105.9 & 23.3 & 167.0 & 0.029 & 0.100 \\
\hline 28 & $\mathrm{k} 28$ & 101.0 & 21.6 & 159.1 & 0.026 & 0.093 \\
\hline 29 & $\mathrm{k} 29$ & 115.6 & 25.4 & 182.3 & 0.031 & 0.109 \\
\hline 30 & $\mathrm{k} 30$ & 89.8 & 19.5 & 142.7 & 0.024 & 0.084 \\
\hline 31 & $\mathrm{k} 31$ & 27.8 & 6.0 & 44.0 & 0.007 & 0.026 \\
\hline 32 & $\mathrm{k} 32$ & 103.5 & 22.7 & 163.7 & 0.028 & 0.098 \\
\hline 33 & $\mathrm{k} 33$ & 87.9 & 18.9 & 137.7 & 0.023 & 0.081 \\
\hline 34 & $\mathrm{k} 34$ & 109.4 & 23.3 & 171.9 & 0.029 & 0.100 \\
\hline 35 & $\mathrm{k} 35$ & 78.1 & 16.8 & 122.9 & 0.021 & 0.072 \\
\hline 36 & k36 & 82.5 & 17.6 & 129.8 & 0.022 & 0.076 \\
\hline 37 & $\mathrm{k} 37$ & 65.9 & 14.3 & 104.7 & 0.018 & 0.062 \\
\hline 38 & $\mathrm{k} 38$ & 82.3 & 17.8 & 130.4 & 0.022 & 0.077 \\
\hline 38 & k39 & 58.2 & 12.6 & 92.9 & 0.015 & 0.054 \\
\hline 40 & $\mathrm{k} 40$ & 120.0 & 26.4 & 189.2 & 0.032 & 0.113 \\
\hline \multicolumn{2}{|c|}{ Average \pm S.E. } & $84.66 \pm 6.21$ & $18.33 \pm 1.34$ & $133.301 \pm 9.70$ & $0.022 \pm 0.001$ & $0.078 \pm 0.005$ \\
\hline
\end{tabular}




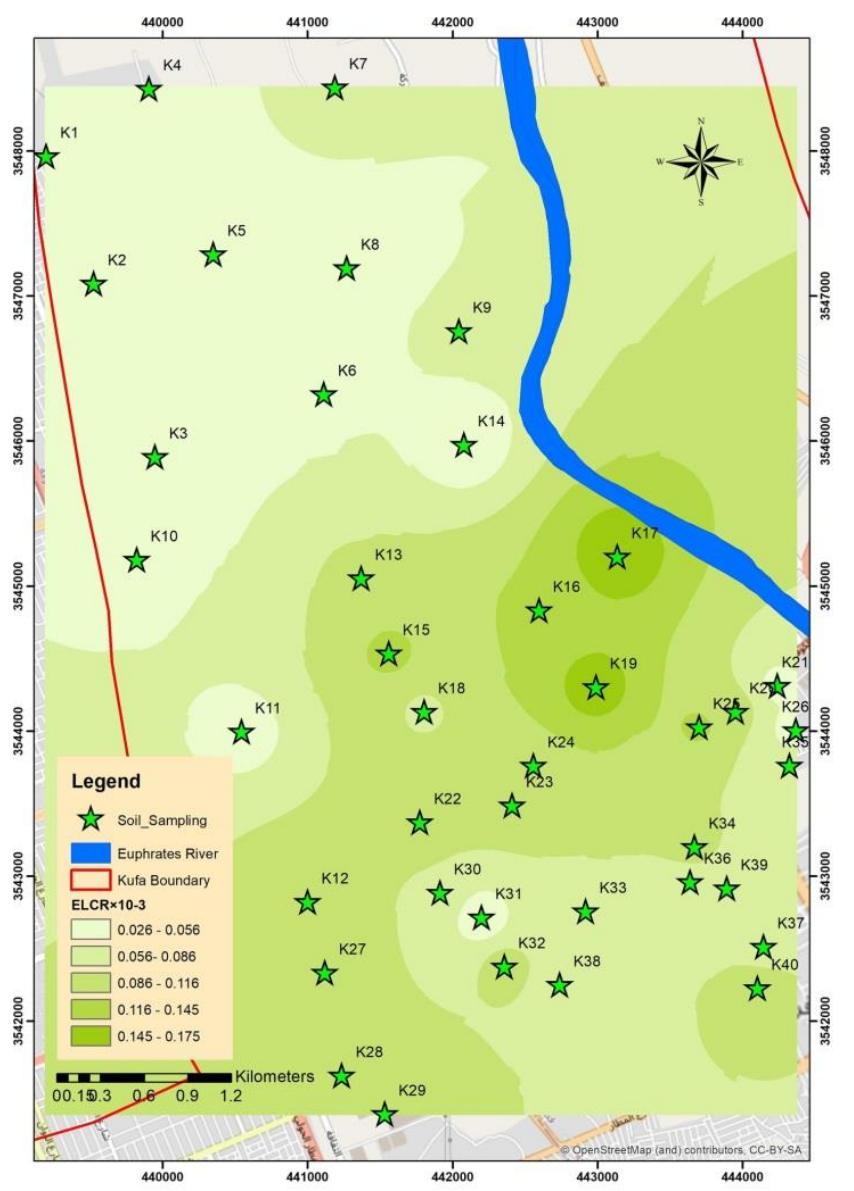

Figure 12. Distribution of ELCR in soil of study area.

239 The results of the specific activity natural radioactivity $\left({ }^{238} \mathrm{U},{ }^{232} \mathrm{Th}\right.$, and $\left.{ }^{40} \mathrm{~K}\right)$ in soil samples of the 240 present study are compared with the previous studies as presented in Table 5. From Table 5, it is 241 found that the specific activity of natural radionuclides for ${ }^{238} \mathrm{U}$ was less than all previous studies, 242 but for ${ }^{232}$ Th are lower than Iraq (Baghdad) and Saudi Arabia, and very close form the recorded 243 value in Iraq (Dhi Qar) and Iran, while for ${ }^{40} \mathrm{~K}$ are less than all previous studied, except in Iran.

245 Table 5. Comparison of the average of the specific activity of ${ }^{238} \mathrm{U},{ }^{232} \mathrm{Th},{ }^{40} \mathrm{~K}$ in this study with previous studies.

\begin{tabular}{|c|c|c|c|c|c|}
\hline \multirow{2}{*}{ No. } & \multirow{2}{*}{ Country } & \multicolumn{2}{|c|}{ The average of the specific activity Bq/kg } & \multirow{2}{*}{ References } \\
\cline { 3 - 5 } & & ${ }^{238} \mathrm{U}$ & ${ }^{232} \mathrm{Th}$ & ${ }^{40} \mathrm{~K}$ & \\
\hline 1 & Iraq (Dhi Qar) & 10.85 & 5.81 & 354.11 & {$[8]$} \\
\hline
\end{tabular}




\begin{tabular}{|c|c|c|c|c|c|}
\hline 2 & Iraq (Baghdad) & 16.5 & 9.7 & 368 & {$[10]$} \\
\hline 3 & Iran & 8 & 5 & 250 & {$[20]$} \\
\hline 5 & Saudi Arabia & 14.22 & 14 & 968.19 & {$[30]$} \\
\hline 6 & Present study & 6.2 & 6.41 & 278.10 & ----- \\
\hline
\end{tabular}

247

\section{Conclusions}

The results of the terrestrial gamma radiation $\left({ }^{238} \mathrm{U},{ }^{232} \mathrm{Th},{ }^{40} \mathrm{~K}\right.$, and $\left.{ }^{235} \mathrm{U}\right)$ as well as

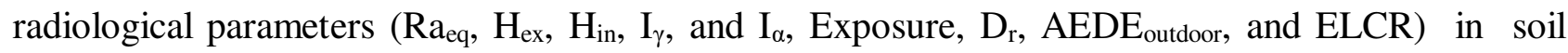
samples of Kufa districts were within the world average values according to UNSCEAR 2008, UNSCEAR 2000, OECD, ICRP1993, and another previous studies. Therefore, it may be concluded that the studied area was safe for the population based on natural radioactivity. Also, it is found that the results of specific activity for potasium-40 > thourium-232 > uranium-238 > uranium-235, because of the most area in the present study was clay minerals and agricultural. The geographic information system (GIS) was a good technique suitable for drawing of natural radioactivity with some radiological parameters in soil samples under study area.

\section{Data availability statement}

The datasets generated during and/or analysed during the current study are available from the corresponding author on reasonable request.

\section{References}

[1] Peirce, J. J., Weiner, R., Matthews, R., \& Vesilind, P. A. (2003). Environmental engineering. Butterworth-Heinemann.

[2] Lehto, J., \& Hou, X. (2011). Chemistry and analysis of radionuclides: laboratory techniques and methodology. John Wiley \& Sons. 
[3] Ojovan, M. I., Lee, W. E., \& Kalmykov, S. N. (2019). An introduction to nuclear waste immobilisation. Elsevier.

[4] Heyde, K. (2020). Basic ideas and concepts in nuclear physics: an introductory approach. CRC Press.

[5] Krane, K. S. (2019). Modern physics. John Wiley \& Sons.

[6] Young, R. (2012). Soil properties and behaviour (Vol. 5). Elsevier.

[7] Abojassim, A. A., \& Rasheed, L. H. (2019). Mapping of Terrestrial Gamma Radiation in Soil Samples at Baghdad Governorate (Karakh Side), Using GIS Technology. Nature Environment and Pollution Technology, 18(4), 1095-1106.

[8] Dhahir, D. M., Mraity, H. A. A., Abojassim, A. A., Najam, L. N., \& Al-kazrajy, H. Y. Y. (2020). Natural radioactivity levels in soil samples of some schools in Al-Shatrah city at Dhi Qar governorate, Iraq. Malaysian Journal of Science, 104-114.

[9] Sanada, Y., Yoshimura, K., Urabe, Y., Iwai, T., \& Katengeza, E. W. (2020). Distribution map of natural gamma-ray dose rates for studies of the additional exposure dose after the Fukushima Daiichi Nuclear Power Station accident. Journal of Environmental Radioactivity, 223, 106397.

[10] Abojassim, A. A., \& Rasheed, L. H. (2021). Natural radioactivity of soil in the Baghdad governorate. Environmental Earth Sciences, 80(1), 1-13.

[11] Hussein, A. K., Kadhim, N. A., Jaber, A. S., \& Abojassim, A. A. (2020, November). Water Quality Index for Surface Water Assessment by Using Gis Techniques, Alnajaf, Kufa, Iraq. In IOP Conference Series: Materials Science and Engineering (Vol. 928, No. 7, p. 072023). IOP Publishing.

[12] Abojassim, A. A., Hamad Al-Gazaly, H., Sabah Obide, E., \& Madlool Al-Jawdah, A. (2020). Radioactivity in samples of cleaning materials. International Journal of Environmental Analytical Chemistry, 100(1), 99-108.

[13] Al-Hamidawi, A. (2014). Assessment of radiation hazard indices and excess life time cancer risk due to dust storm for Al-Najaf, Iraq. Wseas Trans. Environ. Dev, 10, 312. 
[14] Maphoto, K. P. (2004). Determination of natural radioactivity concentrations in soil: a comparative study of Windows and Full Spectrum Analysis (Doctoral dissertation, University of the Western Cape).

[15] Krieger, R. (1981). Radioactivity of construction materials. Betonwerk Fertigteil Techn, 47(468).

[16] Venturini, L., \& Nisti, M. B. (1997). Natural radioactivity of some Brazilian building materials. Radiation protection dosimetry, 71(3), 227-229.

[17] Mahler, R. L., \& Hamid, A. (1994). Evaluation of water potential, fertilizer placement and incubation time on volatilization losses of urea in two northern Idaho soils. Communications in soil science and plant analysis, 25(11-12), 1991-2004.

[18] Abojassim, A. A., Oleiwi, M. H., \& Hassan, M. (2016). Natural radioactivity and radiological effects in soil samples of the main electrical stations at babylon governorate. Yaderna fyizika ta energetika, 17(3), 308-315.

[19] Kahn, B., Eichholz, G. G., \& Clarke, F. J. (1983). Search for building materials as sources of elevated radiation dose. Health physics, 45(2), 349-361.

[20] UNSCEAR.(2008). Sources and effects of ionizing radiation: Report to the general assembly, (United Nations, New York), with scientific annexes,2,1-219.

[21] United Nations Scientific Committee on the Effects of Atomic Radiation. (1988). Sources, Effects and risks of ionizing radiation. UNSCEAR 1988 report to the general assembly, with scientific annexes, New York.

[22] Arafa, W. (2004). Specific activity and hazards of granite samples collected from the Eastern Desert of Egypt. Journal of environmental radioactivity, 75(3), 315-327. 
316 [23] Okogbue, C., \& Nweke, M. (2018). The 226Ra, 232Th and 40K contents in the Abakaliki 317 baked shale construction materials and their potential radiological risk to public health, southeastern 318 Nigeria. Journal of environmental geology, 2(1).

319 [24] UNSCEAR.(1994). Sources and Effects of Ionizing Radiation. UNSCEAR 1994 Report to the 320 General Assembly, with Scientific Annexes. United Nations publications, 49.

321 [25] Tanasković, I., Golobocanin, D., \& Miljević, N. (2012). Multivariate statistical analysis of 322 hydrochemical and radiological data of Serbian spa waters. Journal of geochemical exploration, $323112,226-234$.

324 [26] Nuclear Energy Agency. (1979). Exposure to radiation from the natural radioactivity in 325 building materials: report. OECD.

326 [27] Kaiser, S. (1999). Radiological protection principles concerning the natural radioactivity of 327 building materials. Radiation Protection, 112.

328 [28] United Nations. Scientific Committee on the Effects of Atomic Radiation. (2000). Sources and 329 effects of ionizing radiation: sources (Vol. 1). United Nations publications.

330 [29] ICRP, International Commission on Radiological Protection.(1993). publication 65, Pergamon 331 Press, Oxford, Annals of the ICRP 23(2).

332 [30] El-Taher, A., Alshahri, F., \& Elsaman, R. (2018). Environmental impacts of heavy metals, rare 333 earth elements and natural radionuclides in marine sediment from Ras Tanura, Saudi Arabia along 334 the Arabian Gulf. Applied radiation and isotopes, 132, 95-104. 